University of California, Hastings College of the Law UC Hastings Scholarship Repository

Faculty Scholarship

2010

\title{
Crafting an Amnesty with Traditional Tools Registration and Cancellation
}

Richard A. Boswell

UC Hastings College of the Law, boswellr@uchastings.edu

Follow this and additional works at: http://repository.uchastings.edu/faculty_scholarship

\section{Recommended Citation}

Richard A. Boswell, Crafting an Amnesty with Traditional Tools Registration and Cancellation, 47 Harvard Journal on Legislation 175 (2010).

Available at: http://repository.uchastings.edu/faculty_scholarship/1009

This Article is brought to you for free and open access by UC Hastings Scholarship Repository. It has been accepted for inclusion in Faculty Scholarship by an authorized administrator of UC Hastings Scholarship Repository. For more information, please contact marcusc@uchastings.edu. 


\title{
ARTICLE \\ Crafting an Amnesty with Traditional Tools: Registration and Cancellation
}

\author{
RICHARD A. BOSWELL*
}

\section{INTRODUCTION}

Two pieces of legislation form the cornerstones of modern immigration reform. The first, the Immigration Reform and Control Act ("IRCA"), was enacted by Congress and signed into law by President Ronald Reagan in 1986. ${ }^{1}$ IRCA was proclaimed as a major step towards reform and was touted as the solution to the problem of illegal migration. ${ }^{2}$ The second, the Immigration Act of 1990 ("IMMACT 90"), ${ }^{3}$ attracted far less attention, except from those who closely follow immigration law. IMMACT 90 was seen as the central reform of the legal migration system, specifically the portion of the Act concerning those who may become permanent residents. ${ }^{4}$

Two important components of IRCA were the employer sanction and legalization provisions. ${ }^{5}$ The employer sanction provisions imposed penalties

*Professor of Law, University of California, Hastings College of the Law. This Article is dedicated to my father, William P. Boswell, who dedicated his entire life to the principle that justice, faimess, and kindness should be the driving forces in all human interaction. I also acknowledge the helpful commentary by my colleague and friend Marie Gallagher. This Article could not have been completed without the helpful assistance from Hillary Hardcastle of the Hastings Law Library and my research assistant, Amy Leung. Finally, I could not have completed this project without the constant encouragement and support from my partner in life, Karen Musalo.

${ }^{1}$ See Pub. L. No. 99-603, 100 Stat. 3359 (1986) (codified as amended in scattered sections 8 U.S.C.).

${ }^{2}$ Statement on Signing the Immigration Reform and Control Act of 1986, 2 PUB. PAPERS 1522 (Nov. 6, 1986).

${ }^{3}$ See Pub. L. No. 101-649, 104 Stat. 4978 (1990) (codified as amended in scattered sections of 8 U.S.C.).

${ }^{4}$ Statement on Signing the Immigration Act of 1990, 2 Pub. PAPERS 1717 (Nov. 29, 1990). While the primary thrust of IMMACT 90 was the modification of the employment and family-based immigration scheme, there were provisions in the law that, among other things, made changes to nonimmigrant visas, expanded the definition of aggravated felonies, and increased immigration enforcement. See IMMACT $90 \$ \S 201-31,501-45,104$ Stat. 4978, 5012-28, 5048-67.

s IRCA secs. 101, 201, 100 Stat. 3359, 3360-74, 3394-404. IRCA was a broad set of amendments to the Immigration and Nationality Act, 8 U.S.C. $\$ \$ 1101-1537$ (2006, Supp I. 2007, Supp. II 2008), which also included provisions intended to prevent immigration-related employment discrimination as well as a verification system to prevent new immigrants from accessing certain public benefits. Earlier that year, Congress had enacted the Anti-Drug Abuse Act of 1986, Pub. L. No. 99-570, 100 Stat. 3207 (codified as amended in scattered titles of U.S.C.), which substantially expanded the crimes that could provide the basis for denying status or admission to non-citizens. See IRCA $\S 1751,100$ Stat. at 3207-047 to -048 (codified as amended in scattered sections of 8 U.S.C.). Later amendments, culminating in the major revisions of 1996, further broadened the grounds for inadmissibility and deportability. See Illegal Immigration Reform and Immigrant Responsibility Act of 1996 ("IIRAIRA"), Pub. L. 
on employers who knowingly hired persons who were unauthorized to work in the United States, with the expectation that the pressure would impact the demand side of immigration. 6 The legalization provisions established a broad-based amnesty, which provided temporary legal status to many people who had been in the United States illegally from a date no less than four years prior to the statute's enactment. ${ }^{7}$ IMMACT 90 restructured the legal migration system by re-allocating visas for persons immigrating based on family ties with U.S. citizens or permanent residents or whose skills were needed by U.S. employers. In the years following the passage of the IRCA and IMMACT 90, a large undocumented population ${ }^{8}$ once again confronts the United States, leading to a call for comprehensive reform of the immigration laws, including an amnesty.

This Article will focus primarily on the legalization or amnesty provisions of current immigration reform efforts. ${ }^{9}$ This Article will not explore the deficiencies of the legal immigration system or the reasons employers might hire undocumented workers. Instead, it will focus on how legislation might be crafted so as to maximize the immigration agency's ability to manage the amnesty while dealing with the challenges of a large undocumented population. In proposing a structure for amnesty, this discussion will touch on immigration laws enacted after IRCA, most notably legislation enacted in 1996 that makes current reform and amnesty much more complicated. ${ }^{10}$ This Article's purpose is not to present a justification for an immigration amnesty, for

No. 104-208, div. C, sec. 304,110 Stat. $3009,3009-587$ to -597 (codified as amended at 8 U.S.C. $\$ \$ 1229-1229 \mathrm{c}$ (2006 \& Supp. II 2008)); Antiterrorism and Effective Death Penalty Act of 1996 ("AEDPA"), Pub. L. No. 104-132, 110 Stat. 1214 (codified as amended in scattered titles of U.S.C.); Omnibus Anti-Drug Abuse Act of 1988, Pub. L. No. 100-690, tit. VI, $\$ \$ 7341-50,102$ Stat. 4181, 4469-73 (codified as amended in scattered sections of 8 U.S.C.).

${ }^{6}$ H.R. REP. No. $99-682$, pt. 1 , at $45-46,52$, as reprinted in 1986 U.S.C.C.A.N. 5649 , $5649-50,5656$.

${ }^{7}$ IRCA, sec. 201, 100 Stat. at 3394-404 (codified as amended at 8 U.S.C. § 1255a (2006 \& Supp. II 2008)). IRCA set the cutoff date for most persons who were seeking legalization at January 1, 1982. See 8 U.S.C. $\$ 1255 \mathrm{a}(\mathrm{a})(2)(\mathrm{A})-(\mathrm{B})$. In addition to the cutoff date, the statute also required that the person be able to meet other requirements such as being admissible as an immigrant, not having been convicted of certain crimes, not having participated in the persecution of others, and having registered under the Military Selective Service Act. $\S 1255 \mathrm{a}$ (a)(4).

${ }^{8}$ Estimates of the number of undocumented persons are not easily ascertainable. One source placed the number close to 11.8 million. See infra note 183 .

${ }^{9}$ This Article will use the terms "amnesty" and "legalization" interchangeably, as they are synonymous. The term "legalization" was used in the formal IRCA legislation. Cases, scholarly discussion, and the general public often refer to "amnesty."

${ }^{10}$ See IIRAIRA div. C, sec. 304; AEDPA, 110 Stat. 1214. In enacting IIRAIRA and AEDPA, Congress removed some of the ameliorative devices formerly available in the immigration laws, added additional grounds of inadmissibility and deportability, and also imposed more severe penalties on persons who remained in the United States without permission. This resulted in many undocumented people being permanently barred from obtaining legal status. See Richard A. Boswell, Immigration and Nationaltry Law Cases and Materials 4 (3d ed. 2000). One example of these punitive provisions is 8 U.S.C. $\$ 1182(\mathrm{a})(9)(B)(\mathrm{i})(\mathrm{I})-(\mathrm{II})$ (2006), which makes a person who has been "unlawfully" present in the United States for more than six months or one year inadmissible for three and ten years respectively. A person who has been unlawfully present for more than one year, leaves the United States, and returns without permission is permanently barred from returning unless she can qualify for a waiver. 8 
it appears that some type of amnesty will be a component of whatever comprehensive immigration reform is enacted. ${ }^{11}$ More than anything else, a critical part of the debate will revolve around the terms of the amnesty, such as what cutoff date might be appropriate, whether applicants will be required to leave the country first, the type of documentation they will be required to possess in order to qualify, how absences will be treated, or what acts might disqualify them from eligibility.

In presenting its proposal, this Article first sets forth several guiding principles that underlie amnesty programs. It then draws on two types of immigration relief, which are forms of amnesty in all but name and with which the immigration agency and courts have had much experience: "registry" and "suspension of deportation." 12

\section{Principles for AmNesty}

Four overarching principles provide the foundation for the proposed legislation set forth in this Article. First, the program should be rooted in preserving family unity, meeting the needs for work skills, and fostering our humanitarian values, all of which have long been at the core of U.S. immigration policy. ${ }^{13}$ Second, the program should have as part of its purpose the

U.S.C. § 1182(a)(9)(C)(i)(I) (2006); Sarah Ignatius \& Elisabeth S. Stickney, ImmigraTION LAW AND THE FAMILY $\$ \$ 12.73-74$ (2009).

" See Bryn Siegel, The Political Discourse of Amnesty in Immigration Policy, 41 AKRoN L. REv. 291, 307-09 (2008). While amnesty has been one of the most contentious issues in the political debate, it has been part of major legislation introduced. See, e.g., H.R. 5161, 108th Cong. (2004); H.R. 5040, 108th Cong. (2004); H.R. 10, 108th Cong. (2004); S. 2845, 108th Cong. (2004); H.R. 5024, 108th Cong. (2004); S. 2774, 108th Cong. (2004). In the process of negotiating the political process, legislators have used other terms to describe what might otherwise be characterized as "amnesty." For example, in 2005, Senators Edward Kennedy (D-Mass.) and John McCain (R-Ariz.) introduced something that they called "earned adjustment." See S. 1033, 109th Cong. (2005).

${ }^{12}$ Suspension of deportation was renamed as "cancellation of removal" to conform with immigration legislation enacted in 1996 that eliminated the two separate procedures of exclusion and deportation and melded them into a unitary "removal" proceeding. See IIRAIRA, Pub. L. No. 104-208, div. C, sec. 304, 110 Stat. 3009, 3009-587 to -597 (1996) (codified as amended at 8 U.S.C. $\$ \$ 1229-1229$ c (2006 \& Supp. II 2008)). Prior to IIRAIRA, a person was placed in exclusion proceedings if she was found at the border seeking admission. The person would be placed in deportation hearings if she had managed to gain entry into the United States. See In the Matter of the Application of Imane Phelisna for a Writ of Habeas Corpus, 551 F. Supp. 960 (E.D.N.Y. 1982). A person arriving at the border who was allowed to physically enter under a grant of "parole" would be treated as continuing to seek admission and would face an exclusion hearing.

${ }^{13}$ See, e.g., Immigration Act of 1917, ch. 29, § 19, 39 Stat. 874, 889-90 (repealed 1952) (humanitarian relief of suspension of deportation is provided if "serious economic detriment" would result to the person's U.S. citizen or legal resident alien spouse, parent or minor child); Statement on Signing the Immigration Act of 1990, 2 Pub. PAPers 1717 (Nov. 29, 1990) (President George H. W. Bush recognized that IMMACT 90 "accomplishes what [his] Administration sought from the outset of the immigration reform process: a complementary blending of our tradition of family reunification with increased immigration of skilled individuals to meet our economic needs"). While there are multiple principles underpinning U.S. immigration policy, family unification is central. H.R. REP. No. 101-723 (1990), as reprinted in 1990 U.S.C.C.A.N. 6710, 6711; H.R. REP. No. 89-745, at 1, 12 (1965). Another goal has 
amelioration of unnecessary hardship to the individual seeking amnesty as well as to the community of which the person has become a part. Third, the statutory scheme should be as uncomplicated as possible to minimize the risk of adjudicators and potential beneficiaries adopting multiple or conflicting interpretations. Finally, the government agency charged with implementing the program should be able to administer it relatively easily and the potential beneficiaries of the program should be able to easily understand its provisions.

Three important forces play a key role in driving migration. Family unification has always been a strong force behind migration. ${ }^{14}$ Surely, another reason for much of the migration is a search for work and opportunity-indeed, many migrants come at the behest of employers seeking their work, and in more recent times, employment has become a significant part of migration. ${ }^{15}$ The other historical element of immigration has been humanitarian; many migrants have come to the United States to avoid some form of persecution. ${ }^{16}$ To this day, these three elements of immigration policy serve the important function of fostering a more stable immigrant population. Certainly, an immigrant who is welcomed by family and loved ones, or who comes for employment and remains united with family, will be more easily integrated into the community. ${ }^{17}$ Providing refuge from persecution also

been to balance needs for labor with protection of the domestic workforce. CHARLES GoRDON et al., Immigration LAW AND Procedure $§ 20.03$ [1] (2009). Finally, the humanitarian crisis witnessed in persecutions perpetrated in Hitler's Germany culminated in the codification of international refugee norms with the enactment of the Refugee Act of 1980. Pub. L. No. 96212, 94 Stat. 102 (codified as amended in scattered sections of 8 U.S.C.); GuILLERMina JASSO \& Mark Rosenzweig, The New Chosen People: Immigrants in the United States $338-40$ (1990).

${ }^{14}$ U.S. immigration law, like the laws of many countries, includes provisions for family and employment-based immigration. These are found in the elaborate immigrant quota system, first enacted in 1921 and incorporated into the Immigration and Nationality Act of 1952 and later amendments. See 8 U.S.C. \$ 1153(a)-(b) (2006). In many situations, the immigration laws provide for the admission of non-immigrants with their immediate family members. See Richard A. Boswell, Essentials of Immigration Law 98 (2d ed. 2009) [hereinafter EsSENTIALS OF IMMIGRATION LAw].

${ }^{15}$ Between 1999 and 2008, the total percentage of immigrants who came to the United States under employment-based preferences increased from $8.8 \%$ to $15 \%$. See OfFICE OF IMMIgration Statistics, U.S. Dep't of Homeland Sec., 2008 Yearbook of Immigration StaTistics 18-19 tbl.6 (2009) [hereinafter 2008 IMmigration Statistics]. In the last ten years, employment-based admission peaked in 2005 , at $22 \%$. See id.

${ }^{16}$ Between 1999 and 2008, the total percentage of refugees and asylees who were admitted to the United States increased from $6.6 \%$ to $15 \%$. See id. In the last ten years, refugee and asylee admission was at its peak in 2006 , at $17 \%$. See id.

17 See U.S. Immigration Comm'n, Reports of the Immigration Commission: ABStracts OF Reports of the IMMIGRATION COMmission, S. DOC. No. 61-747 (3d Sess. 1910). The Dillingham Commission found that compared to immigrants who were single, or whose wives and families remained in their native countries, "the process of assimilation [for families] is usually much more rapid [as they] as a rule live in much more wholesome surroundings, and are reached by more of the agencies which promote assimilation." Id. at 42 . The report also found that " $[\mathrm{t}]$ he most potent influence in promoting the assimilation of the family is the children, who, through contact with American life in the schools, almost invariably act as the unconscious agents in the uplift of their parents" and continue the "Americanizing 
serves to meld our values with those in the world community with whom we share international humanitarian norms. ${ }^{18}$

There are two fundamentally different paths that can be taken in fashioning an amnesty or legalization program. One approach would craft a program that is broad in its reach with relatively few requirements. A different approach would create a program crafted to narrow the scope of eligibility for amnesty, which is more punitive than beneficent. To that end, the program could be made to limit the potential beneficiaries and even to have a long set of requirements for each applicant to meet in order to qualify. This more restrictive approach would result in fewer individuals qualifying. It would also attract fewer applicants, undermining the underlying purpose of a comprehensive legalization program. Another relevant consideration in fashioning an amnesty provision is how the requirements are to be interpretedwill interpretations err on the side of inclusion or exclusion? How potential beneficiaries will view an amnesty program's terms is a critical part of the choice regarding the type of amnesty program that should be enacted.

influence" when they become wage earners. Id. A study of Chinese immigrant families found that:

The presence of support from people of the same country of origin and members of the host culture were [sic] likely to facilitate an immigrant's adaptation . . . [as c]ontact with people from the same country reinforced one's sense of self and one's affinity to the heritage culture, whereas contact with people from the host culture facilitated the entry into American society.

Xiaolin Xie et al., Strengths and Challenges in Chinese Immigrant Families, 14 Great PlaIns NAt. Resources J. 203, 216 (2004). Further, in a study of a Vietnamese enclave, research "found that although Vietnamese young people lived in a socially marginal local environment they were shielded from the negative influences of that environment by being tightly bound up in a system of ethnic social relations providing both control and direction," thus leading to a limited involvement in crime. Min Zhou \& Carl Bankston, Delinquency and Acculturation in the Twenty-first Century: A Decade's Change in a Vietnamese American Community, in IMmIGRATION AND CRime: Ethnicity, Race, AND Violence 117, 119-120 (Ramino Martinez, Jr. \& Abel Valenzuela, Jr. eds., 2006).

${ }^{18}$ Protocol Relating to the Status of Refugees, Jan. 31, 1967, 19 U.S.T. 6223. Modern refugee protections were only codified into U.S. law in 1980 in the form of the Refugee Act of 1980. See Pub. L. No. 96-212, 94 Stat. 102. In the period between the end of World War II and the enactment of the Refugee Act of 1980, the legislative responses were focused on the particular crisis of the day. See, e.g., Displaced Persons Act of 1948, Pub. L. No. 80-774, 62 Stat. 1009; Amendment to the Displaced Persons Act of 1948, Pub. L. No. 81-555, 64 Stat. 219; Refugee Relief Act of 1953, Pub. L. No. 83-203, 67 Stat. 400; Immigration and Nationality Act Amendments of 1965, Pub. L. No. 89-239, 79 Stat. 911 . One of the purposes in enacting the Refugee Act was to bring U.S. law into harmony with international humanitarian norms. See S. Rep. No. 590, 96th Cong. 2d Sess. 19 (1980). For an excellent exploration of the efforts which led up to the enactment of the Refugee Act, see Deborah E. Anker \& Michael H. Posner, The Forty Year Crisis: A Legislative History of the Refugee Act of 1980, 19 SAN DIEGO L. REv. 9 (1981). In addition to protecting persons from individualized persecution, the immigration laws include protections for persons facing civil war, political upheaval, civil unrest, and natural disaster. See 8 U.S.C. $\$ 1254$ a (2006). 


\section{Registry, Suspension, and Cancellation of Removal}

For nearly a century, the immigration laws of the United States have used two primary mechanisms to provide immigration status to people who were either in an undocumented status or who had no clear record of having been lawfully admitted to the United States. ${ }^{19}$ The first mechanism-registry-provides blanket lawful permanent residency to non-citizens without status who can prove that they have been in the country since before an established statutory cutoff date. The second-suspension of deportation or cancellation of removal-provides the beneficiary with a grant of lawful permanent resident status as of the date that the relief is granted if the applicant can meet the hardship and physical presence requirements. ${ }^{20}$ While these two forms of relief are not the only methods for conferring permanent residency ${ }^{21}$ they both eliminate grounds for possible deportation and are the closest existing legal parallels to what is commonly regarded as an amnesty. Both methods avoid forcing a person to leave the country and await a possible future return with some legal status. In addition, both forms of relief contain an implicit recognition of the hardships that would be visited on the family and community if a person were forced to depart.

\section{A. Historical Origins of Registry}

In 1917, the United States enacted its first comprehensive immigration legislation in response to the large-scale migration that began in the latter part of the nineteenth century and flowed into the early part of the twentieth century. ${ }^{22}$ The major impetus behind the Immigration Act of 1917 was to place controls on the admission of persons coming to the United States. ${ }^{23}$

\footnotetext{
${ }^{19}$ The term "status" is merely used here to describe the legal position of the person in the United States. The term "undocumented" is a more modern expression ascribed to persons who may be in the country illegally, in the process of seeking status, or simply lacking any legally cognizable status under the immigration laws. For purposes of this discussion, the term is meant to encompass all persons who may be found in the United States, whether inadmissible or deportable, who are not either lawful permanent residents or legally in their nonimmigrant status.

${ }^{20}$ See GoRdon ET AL., supra note $13, \S \S 74.06-07$.

${ }^{21}$ Some persons regularize or gain legal status by applying for adjustment of status, or, if they have the requisite skills or family ties, by obtaining immigrant visas or seeking adjustment of their status. See 8 U.S.C. § 1254a. In other situations, such as where someone would otherwise be ineligible for admission or subject to deportation because of a ground of inadmissibility or deportability, the statute provides for "waivers" of those grounds. See EssENTials OF IMMIGRATION LAw, supra note 14, at 44-48. At the other extreme, others may obtain their permanent residencies through private bills introduced by members of Congress. See ANNA Marie Gallagher, Private Bills and Pardons in Immigration 7 (2008).

${ }^{22}$ Immigration Act of 1917, ch. 29, 39 Stat. 874 (repealed 1952); Edward P. HutchiNson, Legislative History of American Immigration Policy 420 (1981).

${ }^{23}$ The Dillingham Commission, commissioned by Congress to study the impact of immigration in U.S. society, released a forty-two volume study, which concluded that immigration posed a threat to society. See U.S. ImMigration Comm'N, Reports OF THE IMMigration Commission: Abstracts of Reports of the Immigration Commission, S. Doc. No. 61-747, at
} 
Political pressure had been building since the late 1800 s and immigration had reached its historic peak, in both absolute and proportional terms. ${ }^{24}$ The racial component of the anti-immigrant backlash, which arose due to the ethnicities and nationalities of many of these immigrants, was also evident. ${ }^{25}$ Adding to the previously erected racial barriers to the admission of Chinese immigrants in 1882, Congress began setting "qualitative" restrictions such that more and more immigrants began to fall into "undesirable" categories, including the poor, those with health problems, the less educated, and people with various criminal records. ${ }^{26}$ During World War I, the opposition to immigration became particularly strong, culminating in the passage of the Immigration Act of 1917 over President Woodrow Wilson's veto. ${ }^{27}$ A review of the report by what became known as the Dillingham Commission, a committee comprised of House and Senate members that studied immigration to the United States, reveals a strong concern about changes in the country's racial composition. The Commission concluded that the demographic changes that

48 (3d Sess. 1910) ("The Commission as a whole recommend[ed] restriction as demanded by [the] economic, moral, and social considerations, furnish[ed] in its report [and] point[ed] out methods by which Congress can attain the desired result if its judgment coincides with that of the Commission," proposing a "reading and writing test as the most feasible single method of restricting undesirable immigration.").

${ }^{24}$ Available statistics indicate that approximately 14.5 million people immigrated to the United States between 1900 and 1920. See S. ReP. No. 81-1515, at 815 (1950). A review of immigration statistics reveals that nearly 17 million immigrated during a comparable period between 1980 and 2000 with the overall national population in 2000 at approximately 281 million. See Immigration \& Naturalization Serv., U.S. Dep't of Justice, 2000 StatistiCal Yearbook of the Immigration and Naturalization Service 18 tbl.1 (2002). The population of the United States was 106 million in 1920. See Population Estimates Program, U.S. Census Bureau, Historical National Population Estimates: July 1, 1900 TO JULY 1, 1999 (2000), available at http:/www.census.gov/popest/archives/1990s/popclockest.txt.

${ }^{25}$ Beginning in the late 1800 s, the migration patterns had shifted from northern European to southern and eastern European and from Protestant to Catholic. See S. REP. No. 81-1515, at 235; S. Doc. No. 61-747, at 23. At the same time, Jews began arriving in larger numbers. See S. Rep. No. 81-1515, at 235. By the 1880s, migration from Asia had been all but cut off by the Chinese Exclusion Act and other efforts. Act of May 6, 1882, ch. 126, 22 Stat. 58, amended by Act of July 5, 1884, ch. 220, 23 Stat. 115 (repealed 1943). This amending provision prohibited the admission of Asians to the United States, and the Supreme Court upheld these laws in the "Chinese Exclusion Case," Ping v. United States, 130 U.S. 581, 606-09 (1889). Japanese migration was closed off through the so-called "Gentleman's Agreement" between Japan and the United States in 1907. See H.R. ReP. No. 82-1365 (1952), as reprinted in 1952 U.S.C.C.A.N. 1313, 1664. In 1917, Congress barred immigration from the Asia-Pacific Triangle altogether. Immigration Act of 1917, 39 Stat. 874.

${ }^{26}$ Immigration Act of Feb. 20, 1907, Pub. L. No. 59-96, 34 Stat. 898. The Act of 1907 , among other things, increased the head tax on those coming to the country to four dollars and added provisions relating to those with physical and medical conditions affecting their ability to earn a living and to unaccompanied children.

${ }^{27}$ See 54 Cong. Rec. 2626, 2629 (1917). A Joint Commission on Immigration, created in 1907 , resulted in the dissemination of a report in 1911, culminating in the passage of the Immigration Act of 1917. Immigration Act of February 20, 1907, Pub. L. No. 59-96, § 39, 34 Stat. 898, 909; S. Doc. No. 61-747. 
had been taking place in the United States needed to be changed dramatically. ${ }^{28}$

In this climate, numerous new limitations were put into place, leading to the establishment of the first quota restrictions in $1921 . .^{29}$ These quota restrictions were designed to control the admission of new immigrants in order to change the racial composition of the United States. Immigrants without legal status who had established ties within the community were caught within these restrictions. The legal mechanism adopted to deal with this group of people-registry-converted the person's last established admission date into a "record of lawful admission," thereby making him eligible for naturalization. ${ }^{30}$

Registry has been a part of the immigration laws since $1929,{ }^{31}$ and the qualifying cutoff date for the benefit has been amended numerous times. The first registry date was set at June $3,1921^{32}$ and was later moved to July 1 , $1924,{ }^{33}$ June $28,1940,{ }^{34}$ June $30,1948,{ }^{35}$ and most recently to January 1 , $1972 .{ }^{36}$ While proponents of advancing the registry date were not able to expand the reach of the benefit, a number of modifications were enacted over the years. Establishing a record of admission date enabled the recipient to seek naturalization because the admission was effectively backdated. ${ }^{37}$ The clear intent of the first registry was to create a record of lawful admission for anyone who had entered the country prior to the June 3, 1921 date, ${ }^{38}$ thereby granting a type of amnesty, permanent residency, and an opportunity

\footnotetext{
${ }^{28}$ See S. Doc. No. 61-747, at 45. Many of the concerns presented in the Dillingham report also appear in the 1950 report that served as the foundation for the McCarran-Walter Act of 1952. See S. REP. No. 81-1515, at 805; see also A.J. McLaughlin, Immigration and the Public Health, 29 Pub. Health Papers \& Rep. 224, 224 (1903) ("With the change in the racial character of immigration, most marked in the past decade, a pronounced deterioration in the general physique of the immigrants, and a much higher percentage of loathsome and dangerous diseases is noticeable.").

${ }^{29}$ Act of May 19, 1921, ch. 8, 42 Stat. 5. While the quotas set in 1921 were "temporary," they were made permanent in 1924. See Immigration Act of 1924, ch. 190, 43 Stat. 153 (repealed 1952).

${ }^{30}$ Hutchinson, supra note 22 , at 563 .

${ }^{31}$ Registry Act of 1929, ch. 536, § 1(a)(1), 45 Stat. 1512, 1513 (repealed 1940).

${ }^{32}$ Id.

${ }^{33}$ Act of Aug. 7, 1939, ch. 517, 53 Stat. 1243 (amending the Registry Act of 1929 $\S 1(\mathrm{a})(1))$. The McCarran-Walter Act of 1952 did not change the registry date. See Immigration and Nationality Act of 1952, ch. 477, $\S 249,66$ Stat. 163, 219 (codified as amended at 8 U.S.C. \& 1259 (2006)). The "McCarran-Walter Act of 1952" is the common name for the comprehensive immigration amendments enacted in the Immigration and Nationality Act of 1952, which form the foundation for modern immigration law. See id.

${ }^{34}$ Act of Aug. 8, 1958, Pub. L. No. 85-616, 72 Stat. 546 (codified as amended at 8 U.S.C. $\S 1259)$.

${ }^{35}$ Act of Oct. 3, 1965, Pub. L. No. 89-236, § 19, 79 Stat. 911,920 (codified as amended at 8 U.S.C. $\$ 1259$ ).

${ }^{36}$ IRCA, Pub. L. No. 99-603, § 203(a)-(b), 100 Stat. 3359, 3405 (1986) (codified at 8 U.S.C. $\$ 1259)$.

${ }^{37}$ See Registry Act of 1929, ch. 536, § 3, 45 Stat. 1512, 1513 (repealed 1940). This is one of the reasons why a person who seeks registry must not be ineligible for citizenship, since the original purpose of registry was to allow the person to proceed to naturalization.

${ }^{38}$ See id. ch. 536, § 1(a)(1), 45 Stat. at 1513.
} 
to apply for citizenship ${ }^{39}$ One impetus for creating registry was that, with the 1906 enactment of stricter rules requiring the registration of all persons coming to the United States, there were many people with sympathetic cases who did not have documents evidencing their records of admission. ${ }^{40}$ With the increased enforcement of deportation statutes, some legal mechanism was necessary to regularize the statuses of these people and allow them to apply for citizenship. ${ }^{41}$ A powerful justification for this procedure was that these people were already interwoven into the community, as many of them had created families in the United States. Registry provided a fairly broad and comprehensive vehicle for granting legal status to its beneficiaries. The creation of this immigration relief was, in effect, the creation of a "record of [lawful] admission," which otherwise had not previously existed. Another way to view registry was that it created a form of a statute of limitations on removal for a narrowly defined group. ${ }^{42}$

There were relatively few requirements to qualify for the earlier registry: proof of physical entry before the cutoff date, good moral character, and not being subject to deportation or ineligible for U.S. citizenship. ${ }^{43}$ Later amendments to the registry requirements replaced the deportability provision with one that proscribed registry for persons who were inadmissible based on more serious exclusion grounds. ${ }^{44}$

Precise information regarding the number of persons who applied for and received registry is unavailable for the period between 1932 and 1945. However, records do show that a number of undocumented persons were able to take advantage of the program in its first years. According to the

${ }^{39}$ This differed from amnesty in 1986, which granted temporary status and only allowed a person to apply for citizenship five years after she was granted permanent residency. A person granted amnesty would first receive temporary residence. See 8 U.S.C. \& 1255a(a) (2006). They would be eligible to apply for permanent residence nineteen months after having been granted temporary residence. See 8 U.S.C. $\S 1255$ a(b)(1)(A). A person would be eligible to apply for naturalization after they had been been a lawful permanent resident for at least five years. See 8 U.S.C. $\$ 1427$ (2006).

${ }^{40}$ Act of June 29, 1906, ch. 3592, § 1, 34 Stat. 596, 596 (repealed 1940). The 1906 Act established the Bureau of Immigration and Naturalization and required the Commissioner to "cause a registry to be made in the case of each alien arriving in the United States." Id. The Act further provided that the person be granted a certificate of registry. Id. The registry established in the 1929 legislation effectively created a record of registry where there previously was none. See Registry Act of 1929, 45 Stat. 1512.

${ }^{41}$ At the time, it was understood that people who had been in the country for a continuous period of eight years should be eligible to apply for citizenship. HuTCHINson, supra note 22, at 563.

${ }^{42}$ Few provisions of the immigration laws contain statutes of limitations. As long as a person is a non-citizen, she is subject to the immigration provisions relating to grounds of inadmissibility and deportability. A person who becomes naturalized remains subject to denaturalization if she was originally ineligible for naturalization. Act of March 2, 1929, Pub. L. No. 70-962, ch. 536, 45 Stat. 1512.

${ }^{43}$ Id. The reference to "ineligibility for U.S. citizenship" was meant to prohibit Asians from being granted registry, as they remained ineligible for citizenship until the 1940s.

${ }^{44}$ See Act of Aug. 8, 1958, Pub. L. No. 85-616, 72 Stat. 546 (codified as amended at 8 U.S.C. $\$ 1259$ (2006)). The statute used the language "criminals, procurers and other immoral persons, subversives, violators of the narcotic laws or smugglers of aliens." Id. 
Commissioner General of Immigration, during the first year of registry, 18,800 applications were filed, and by the end of the year, nearly half of those were adjudicated, with 8098 approved and 1125 denied. ${ }^{45}$ The Commissioner's 1931 report revealed that the number of certificates of registry issued increased substantially that year. ${ }^{46}$ An analysis of the numbers in 1931 show that more than $60 \%$ of applicants entered the country between 1911 and 1921 , approximately $25 \%$ between 1901 and 1910 , and $12 \%$ prior to $1901 .{ }^{47}$ The number of applications for registry dropped to 14,414 in $1932 .{ }^{48}$ The Commissioner General of Immigration expressed concern that the high filing fee and the unemployment rate at the time caused this decrease in applications. ${ }^{49}$ While detailed information is not available disaggregated by year between 1929 and 1945, it appears that during this period more than 200,000 persons were granted registry, with the number of applicants remaining at approximately 10,000 per year through 1939.50 The number of applicants increased substantially with the advancement of the date in 1939, reaching its peak in 1943, and then dropping from 1944 to $1946 .^{51}$ Even with the enactment of the amendments to the registry date in 1958, the number of persons granted registry did not increase substantially. ${ }^{52}$ Indeed, the agency estimated that the total number of beneficiaries would be between 10,000 and 15,000 persons..$^{53}$ In reality, until the registry date was advanced to 1948 , the number of applications diminished steadily to a low of 2326 in $1965 .{ }^{54}$

45 See Bureau of Immigration, U.S. Dep't of Labor, Annual Report of the CommisSioner General of ImMigration to the Secretary of Labor 27 (1930).

46 See Bureau of Immigration, U.S. Dep't of Labor, Annual Report of the CommisSIONER General of Immigration to the Secretary of Labor 46 (1931). The number of certificates of registry issued nearly doubled in 1931 from the previous year's 8098 to 16,242 . Id.

${ }^{47}$ The report provides the breakdown as follows: prior to 1901,$1985 ; 1901$ to 1910,4096 ; and 1911 to $1921,10,161$. Id.

${ }^{48}$ Bureau of Immigration, U.S. Dep't of Labor, Annual Report of the CommisSioner General of ImMigration to the Secretary of Labor 36 (1932) [hereinafter 1932 IMMIGRATION REPORT].

${ }^{49} \mathrm{ld}$.

50 Immigration \& Naturalization Serv., U.S. Dep't of Justice, Annual Report of the Immigration and Naturalization Service 24 (1946).

${ }^{51}$ Id.

52 Immigration \& Naturalization Serv., U.S. Dep't of Justice, Annual Report of the IMmigration and Naturalization Service 1959 4. While the amendment was not enacted until August 1958, the report for the fiscal year reveals that 4321 persons were granted registry, of which only 1309 had entered between July 1, 1924 and June 28, 1940, the new cut off date. $I d$.

${ }^{53} \mathrm{Id}$. Even in the fiscal years that followed the advancement of the registry date to June 28,1940 , most of the persons granted the benefit had entered the country prior to July $1,1924$. See Immigration \& Naturalization Serv., U.S. Dep't of Justice, Annual Report of the IMMigration AND Naturalization SERvice 19615 ("more than three fourths ... entered the United States prior . . ."); Immigration \& Naturalizatjon Serv., U.S. Dep't of Justice, AnNual Report of the Immigration and Naturalization Service 19604 ("two thirds of the cases ... had entered ... prior").

54 See Immigration \& Naturalization Serv., U.S. Dep'T of Justice, Annual Report of THE IMMIGRation and Naturalization SERVICE 19655 [hereinafter 1965 IMMIGRATION RePORT] (2326 persons granted registry); ImMigRation \& NATURALIZATION SERV., U.S. DEP'T 
Even with the 1965 advancement of the registry date to June 30,1948 , the number of registry beneficiaries never exceeded 2887 per year, the peak reached in fiscal year 1966.55 The numbers remained well below 1000 beneficiaries per year until the registry was advanced to January 1, 1972 in 1986.56

The current version of registry, formulated when Congress established the Amnesty of 1986, set the registry date at January 1, 1972.57 In order to qualify, an applicant must have been in the United States unlawfully any time since before the cutoff date (January 1, 1972), be of good moral character, not be ineligible for U.S. citizenship, and not be deportable as a terrorist or a Nazi. ${ }^{58}$ The same inadmissibility grounds under previous registry would also preclude a granting of relief. ${ }^{59}$ A registry applicant may apply for the benefit whether or not she is in removal proceedings, meaning that she may affirmatively present herself before the agency and seek the benefit, or, if she is facing proceedings, she may make the application as a defense to her

of Justice, Annual Report of the Immigration and Naturalization Service 19645 (2916, reflecting a 7\% reduction from the previous year); IMMIGRATION \& NATURALIZATION Serv., U.S. Dep't of Justice, ANnual Report of the Immigration and Naturalization SERVICE 19636 (3133 applicants, reflecting a reduction of $13 \%$ from the previous year).

${ }^{55}$ Immigration \& Naturalization SERv., U.S. DeP'T OF Justice, ANNual Report of THE ImMigration and Naturalization SERvice 19678.

${ }_{56}$ The agency report for 1984 noted that the registry cases from 1979 to 1984 never exceeded 262 cases and diminished during that period, with 111 persons receiving registry in 1984. See Immigration \& Naturalization Serv., U.S. DeP't OF Justice, 1984 Statistical Yearbook of the Immigration and Naturalization Service 14. According to the 1987 Statistical Yearbook of the Immigration and Naturalization Service, the number of persons granted registry was 8153 , which represented a dramatic increase from prior years. IMMIGRAtion \& Naturalization Serv., U.S. Dep't of Justice, 1987 Statistical Yearbook of the Immigration and Naturalization Service 11 (1988). However, this number is still extremely small given the 790,000 applicants under the legalization program in that same period. Id. at 44

${ }^{57}$ See IRCA, Pub. L. No. 99-603, sec. 203(a)-(b), 100 Stat. 3359, 3405 (1986) (codified at 8 U.S.C. $\$ 1259(2006))$.

${ }^{58} 8$ U.S.C. $\$ 1259$ provides that:

A record of lawful admission for permanent residence may, in the discretion of the Attorney General and under such regulations as he may prescribe, be made in the case of any alien, as of the date of the approval of his application or, if entry occurred prior to July 1, 1924, as of the date of such entry, if no such record is otherwise available and such alien shall satisfy the Attorney General that he is not inadmissible under section section $1182(a)(3)(E)$ of this title or under section 1182(a) of this title insofar as it relates to criminals, procurers and other immoral persons, subversives, violators of the narcotic laws or smugglers of aliens, and he establishes that he-

(a) entered the United States prior to January 1, 1972;

(b) has had his residence in the United States continuously since such entry;

(c) is a person of good moral character; and

(d) is not ineligible to citizenship and is not deportable under section $1227(\mathrm{a})(4)(\mathrm{B})$ of this title.

$\$ 1259$. Literally what occurs is that the person's established entry date is converted to a record of lawful admission thereby enabling the person to remain in the country and should she desire, apply for naturalization.

${ }^{59}$ Id. 
removal ${ }^{60}$ The applicant is required to show that she has maintained continuous "residence" in the United States since January 1, 1972." Arguably, a person who qualifies for registry and is returning from a short trip abroad should also be able to seek registry in the event that she is placed in proceedings upon return. ${ }^{62}$ In addition, the applicant is required to show that she is not ineligible on account of certain criminal grounds, including prostitution, subversive activities, narcotics, or alien smuggling. ${ }^{63}$ For a person who has been granted registry, the grounds of inadmissibility, which would normally be applicable to her, may be waived, since at the conclusion of the process she is granted lawful permanent residency as of the date her application is approved. ${ }^{64}$ This differs from the status accorded to beneficiaries of the 1986 amnesty who initially only received temporary residency and then could apply for permanent residency two years later. ${ }^{65}$

One of the requirements under registry is that the person be able to show that they have been "continuously" resident in the United States throughout the statutory period. ${ }^{66} \mathrm{By}$ the terms of the statute, the relief is only available to persons who are not in a legal status or who were not admitted as such. ${ }^{67}$ Continuous residence allows for breaks in a person's physical presence in the country. ${ }^{68}$ The determination of what constitutes "residence" involves consideration of the person's regular place of general abode without regard to intent. ${ }^{69}$ This means that a person who has had her physical home in the United States since January 1, 1972 and could show

${ }^{60} 8$ C.F.R. $\S 1249.2($ a) (2008).

${ }^{61} 8$ U.S.C. $\$ 1259$.

${ }^{62}$ Existing regulations provide that registry is available in removal proceedings "other than [for] an arriving" person. See 8 C.F.R. $\$ \S 249.2(a), 1249.2(a)$ (emphasis supplied). All other applicants must seek registry benefits before the district director. Id. The regulations may be a misapplication of the law because they fail to consider the amendments enacted in 1996, which redefined when a person is seeking admission to include persons who were not lawfully admitted. IIRAIRA, Pub. L. No. 104-208, div. C, sec. 301(a), 110 Stat. 3009, 3009-575 (1996) (codified at 8 U.S.C. $\$ 1101(\mathrm{a})(13)(\mathrm{A})(2006)$ ).

${ }^{63}$ See 8 U.S.C. $\$ 1259$.

${ }^{64}$ See 8 C.F.R. $\$ \S 249.1,1249.1$. The term "inadmissibility" is used since a person who is illegally in the United States remains inadmissible following the enactment of IIRAIRA. 8 U.S.C. $\$ 1101(\mathrm{a})(13)(A)$. Prior to IIRAIRA, a person who illegally entered the country was subject to grounds of deportability. See 8 U.S.C. $\$ 1251$ (a)(1)(B) (1994).

${ }^{65}$ See supra note 39 . In addition, each amnesty applicant had to individually qualify. This means that a spouse could not accord temporary residence or amnesty to her spouse and children. This is unlike most forms of traditional immigrant benefits where the derivative status is extended to the immediate family members. See EsSENTIALS OF IMMIGRATION LAw, supra note 14 , at $135-36$.

668 U.S.C. $\$ 1259$ (b).

${ }^{67} 8$ U.S.C. $\$ 1259$. For example, a person who was admitted as a permanent resident, or who initially had entered illegally and then later became a permanent resident, could not use the relief as a way of avoiding removal. See Angulo-Dominguez v. Ashcroft, 290 F.3d 1147, 1151 (9th Cir. 2002); In re M-P_, 9 I. \& N. Dec. 747, 749 (B.I.A. 1962).

${ }^{68}$ See 8 U.S.C. $\$ \S 1101$ (a)(33), 1259(b) (2006); In re Jalil, 19 I. \& N. Dec. 679 (B.I.A. 1988). But see Manzo-Fontes v. Immigration \& Naturalization Serv., 53 F.3d 280, 283 (9th Cir. 1995) (thirteen-month stay in Mexico rendered applicant's residency “discontinuous").

${ }^{69}$ See 8 U.S.C. $\$ 1101(\mathrm{a})(33)$. 
that she has continued to live in the United States throughout this time, despite absences, would still be able to meet the requirements of the statute.

Because only those who are able to show both entry and continuous residence since January 1, 1972 are eligible for the current version of registry, it is rarely a viable remedy. ${ }^{70}$ In order to qualify for registry, a person would have to have lived in the United States without authorization for nearly four decades. Such a person would likely be able to avail himself of other immigration remedies. ${ }^{71}$ With a fixed, rather than rolling, cutoff date, the pool of eligible persons will not likely grow. The legislative history on the advancement of the registry date to 1972 is silent as to why that, and not another date closer to 1986 , was selected. ${ }^{72}$ Obviously, any date used for registry is the product of compromise. When enacted, the 1986 amnesty was already viewed by its critics as a significant compromise and a reward for illegal immigration..$^{73}$ The decision to use the 1972 cutoff rather than a more recent registry date reflected the more restrictive of the possible choices or perhaps that temporary status was more politically acceptable than a permanent status such as registry.

While the first registry was enacted following a period of large-scale migration and after strict controls had been put into place, the 1986 amnesty was established during increased immigration and coupled with strong enforcement provisions. ${ }^{74}$ During the depression years, immigration dropped significantly, and many of those who had come earlier in the century began to return to their native countries. ${ }^{75}$ It was not until the early 1970 s that the

${ }^{70}$ See supra note 58 and accompanying text. In 1990, the number of registry beneficiaries was 4633 and, in 1997, the number had fallen to 195. ImMigration \& Naturalization Serv., U.S. Dep't of Justice, 1997 Statistical Yearbook of the Immigration and NatuRALIZATION SERVICE 32 (1999).

${ }^{71}$ For example, if a person can establish the requisite level of hardship, she may apply to obtain cancellation of removal. See discussion infra note 103 and accompanying text. If she has a qualifying family relationship with a U.S. citizen or permanent resident, she might seek an immigrant visa or adjustment of status. See Essentials of IMMigration Law, supra note 14, at 133-34. If the person has an occupation or skills that are in short supply, she might be able to obtain permanent residency based on a U.S. employer's need for those skills. Id. at 141-51.

${ }_{72}$ Rep. Bill McCollum (R-Fla.) introduced a proposal that would have advanced the registry date to 1976, but it never received sufficient support. See 132 Cong. REC. 29,990 (1986).

${ }^{73}$ Indeed, one senator indicated his opposition to the 1986 legislation during the congressional debates by saying that he "must oppose the principle that, in legalizing those who have entered the country illegally, we will be rewarding lawbreakers. [IRCA is] a slap in the face to legal aliens who now reside here, it is a slap to those who continue to wait, [and] it sets an untenable and undesirable principle for dealing with future lawbreakers. We should not reward those who have successfully violated U.S. immigration policy, those who can prove they have broken U.S. law." 132 CoNG. REC. 33,235 (1986) (statement of Sen. Hubert Humphrey (DMinn.)).

${ }^{74}$ Immigration levels reached a peak in the early 1900 s, but fell significantly after the immigration legislation of 1917. See, e.g., 2008 Immigration Statistics, supra note 15, at 18-19 tbl.1 (showing that the number of persons granted permanent resident status fell from 295,403 in 1917 to 110,618 in 1918 ).

${ }^{75}$ See Deportation of Criminals, Preservation of Family Units, Permit Noncriminal Aliens to Legalize Their Status: Hearing on S. 2969 Before the Subcomm. on Immigration of the H. 
number of foreigners coming to the United States began to increase beyond the level of the quota restrictions, and it was only in the 1980s and 1990s that the level of immigration reached rates comparable to those of the early $1900 \mathrm{~s} .{ }^{76}$ Therefore, using a January 1972 cutoff date for registry guaranteed that only a relatively small group would qualify, as the significant increase in immigration did not occur until after that date.

In examining registry, it is useful to track how it was used before and after the passage of the McCarran-Walter Act of 1952. ${ }^{77}$ The first registry, enacted in 1929, set a cutoff date in 1921, a date that preceded the Act by eight years. ${ }^{78}$ The 1939 amendment set the registry date at 1924, an advance of only three years over a period of twenty-three. ${ }^{79}$ Congress did not advance the registry date when it enacted the most comprehensive immigration reform in history in $1952 .{ }^{80}$ It was not until the 1958 amendments that Congress advanced the registry date by sixteen years to $1940 . .^{81}$ The next advancement occurred in 1965 , moving the date by eight years to $1948 .{ }^{82}$ Finally, the most recent advancement occurred in 1986, when the date was moved ahead twenty-four years to $1972 .{ }^{83}$ While the first registry date was set much closer to its enactment, later amendments did not follow this ameliorative objective. Each successive registry advancement appears to have been established to deal with the undocumented population of the time and resulted from a realization that the creation of relief was favorable to other alternatives. ${ }^{84}$

Comm. on the Judiciary, 74th Cong. 13-14 (1936) (statement of Colonel D. W. MacCormack, U.S. Comm'r of Immigration \& Naturalization, Department of Labor) (noting that in the preceding five years, 289,000 more people had left the United States than had entered).

${ }^{76}$ See Bill Ong Hing, Defining America Through Immigration Policy 98 (2004). These backlogs in immigrant visas have persisted to the present in many of the family preference categories. A review of the Visa Bulletin issued monthly by the Department of State from 1995 to the present can be found at Visa Bulletin, http://ravel.state.gov/visa/frvi/bulletin/bulletin 1770.html (last visited Nov. 1, 2009). The numbers of persons who were granted permanent residency in 1907 and 1914 exceeded 1.2 million, and that number was only reached again in 1990 when it reached 1.5 million. See 2008 Immigration Statistics, supra note 15, at 18-19 tbl.1.

${ }^{77}$ The "McCarran-Walter Act of 1952" is the common name for the comprehensive immigration amendments enacted in 1952, which form the foundation for modern immigration law. See ch. 477, 66 Stat. 163 (1952) (codified as amended in scattered titles of U.S.C.).

${ }^{78}$ Registry Act of 1929, ch. 536, § 1(a)(1), 45 Stat. 1512, 1513 (repealed 1940).

${ }^{79}$ Act of Aug. 7, 1939, ch. 517, 53 Stat. 1243 (amending the Registry Act of 1929 $\S 1(\mathrm{a})(1))$

${ }^{80}$ See McCarran-Walter Act of $1952 \S 249,66$ Stat. at 219 (codified as amended at 8 U.S.C. $\S 1259(2006))$.

${ }^{81}$ Act of Aug. 8, 1958, Pub. L. No. 85-616, 72 Stat. 546 (codified as amended at 8 U.S.C. $\S 1259$ ).

${ }^{82}$ Act of Oct. 3, 1965, Pub. L. No. 89-236, $\S 19,79$ Stat. 911,920 (codified as amended at 8 U.S.C. § 1259). $\$ 1259$ )

${ }^{83}$ IRCA, Pub. L. No. 99-603, sec. 203(a)-(b), 100 Stat. 3359, 3405 (codified at 8 U.S.C.

${ }^{84}$ It is noteworthy that soon after the enactment of the first registry in 1929 , the Commissioner General was concerned that many who were otherwise qualified would not apply because of the high filing fee: 
Over the years since registry was first enacted, there have been attempts either to expand its reach or to advance the cutoff date. For example, in 1933, legislation that had been passed by the House of Representatives and reported to the Senate would have advanced the registry date to July 1, $1924 .{ }^{85}$ The proposal failed, however, because the congressional session ended before the two bills could be reconciled and put to a vote. ${ }^{86}$ In 1934 , various registry bills were introduced in both houses of Congress, the most generous of which would have removed the registry date and replaced it with a ten-year continuous residency requirement. ${ }^{87}$ While efforts at reform of the registry provisions continued through several congressional sessions, no agreement was reached on these immigration proposals. ${ }^{88}$ In 1962 , an effort was made to enact a change that, among other things, would have moved the registry date to December $24,1952 .{ }^{89}$ But after a series of amendments, Congress amended the suspension of deportation statute instead of changing the registry date. ${ }^{90}$ During the $1970 \mathrm{~s}$, there were renewed discussions of possible advancement of the registry date, ${ }^{91}$ but none of these materialized into positive legislation until enactment of the IRCA in 1986.

The applications for registry have shown continuing decreases, there having been 18,800 two years ago. This does not mean that the field is being exhausted, but is a reflection of the distressing unemployment situation, as the application fee of $\$ 20$ looms large in these times, and so can not be spared even for this desirable purpose.

1932 IMMIGRATION REPORT, supra note 48 , at 36.

${ }^{85}$ H.R. 8174, 72d Cong. (1933). As noted in the Commissioner General's report, the agency supported the advancement of the registry date. See REPORT OF THE COMMISSIONER GENERAL OF IMMIGRATION 36-37 (1932).

${ }^{86}$ See H.R. 8174 . The bill was passed by the Senate, but because the version differed from the one that had been passed by the House and could not be reconciled and voted on again, it failed to become law. See 76 CONG. REC. 5522-24 (1933).

${ }^{87}$ See S. 3769, 73d Cong. (1934); H.R. 9760, 73d Cong. (1934). This ten-year period would have allowed anyone to qualify for permanent residency who had been in the United States for the prescribed period, could establish good moral character, and did not fit within the exclusions. See H.R. REP. No. 73-1827 (1934).

${ }^{88}$ During the 74 th Congress in 1936 , legislation was introduced which would have both provided for suspension of deportation for persons in an illegal status for ten continuous years and also would have changed the registry cutoff date from July 3, 1921 to July 1, 1924. See S. 2969, 74th Cong. $\S \S 3,5$ (1936).

${ }^{89}$ S. 3361, 87th Cong. $\$ 4$ (1962); H.R. 11,911, 87th Cong. $\$ 4$ (1962).

${ }^{90}$ The amendments created the two-tiered suspension of deportation language of seven and ten years of residency depending on the basis for a person's deportability. The statute provided that where a person was deportable for past crimes she would be required to show a higher degree of hardship (extremely exceptional and unusual) and ten years of continuous physical presence. On the other hand, if the person had no disqualifying criminal behavior, she would be required to show a lesser degree of hardship (extreme hardship) and seven years of continuous physical presence. See Act of Oct. 24, 1962, Pub. L. No. 87-885, § 4, 76 Stat. $1247,1247-48$ (repealed 1996).

${ }^{91}$ See H.R. 8713, 94th Cong. $\$ 4$ (1975); COMm. ON THE Judiciary, 94TH Cong., Amending the ImMigration and Nationality ACt, and For Other Purposes, H.R. ReP. No. 94506, 16-17 (Comm. Print 1975). 


\section{B. Historical Origins of Suspension/Cancellation Relief}

Until 1940, U.S. immigration laws included provisions allowing a person to escape deportation, even if only on a temporary basis. ${ }^{92}$ For example, section 3 of the Immigration Act of 1917 gave the Secretary of Labor authority to allow the admission of unaccompanied children under the age of sixteen. ${ }^{93}$ Another section authorized the discretionary readmission of persons who were returning to their unrelinquished domicile of at least seven consecutive years..$^{94}$

With the exception of registry, it was not until 1940 that the immigration laws were amended to include a provision that allowed persons who were otherwise illegally in the country to receive protection in the form of permanent residency. To be granted permanent residency, the Alien Registration Act of 1940 required that a person establish good moral character for the preceding five years and show that her deportation would result in serious economic detriment to a spouse, parent, or minor child, who was either a permanent resident or U.S. citizen. ${ }^{95}$ Under the 1940 Act, a person's deportation would be "suspended" for six months, at which time a report would be made to Congress. ${ }^{96}$ The person would then be granted permanent residency unless a joint resolution was issued by both houses of Congress objecting to the permanent suspension of the person's deportation. ${ }^{97}$ Thus, absent Congressional action, a decision granting suspension of deportation would result in permanent residency. ${ }^{98}$

Congress enacted these provisions in 1940 after hearing accounts of the hardships faced by the family members of persons subject to the rigid depor-

${ }^{92}$ The Act of June 25, 1798 authorized the President to order the detention and deportation of "all such aliens as he shall judge dangerous to the peace and safety of the United States," and it simultaneously gave the President the power to allow such persons to remain in the country, effectively suspending or staying their deportation. Act of June 25,1798 , ch. $58, \S 1$, 1 Stat. 570, 571. A later statute enacted in 1903 allowed the Commissioner General of Immigration to suspend the deportation of persons not in compliance with the contract labor provisions. Act of Mar. 3, 1903, ch. 1012, $\S 19,32$ Stat. 1213, 1218. The Act of February 20, 1907 allowed the temporary suspension of deportation for persons whose testimony was needed in enforcing the provisions of the Act governing the detention and deportation of inadmissible persons. See Act of Feb. 20, 1907, ch. 1134, § 19, 34 Stat. 898, 904; In re Aliens, 231 F. 335, 337-39 (N.D.N.Y. 1916).

${ }^{93}$ Act of Feb. 5, 1917, ch. 29, $\S 3,39$ Stat. 874, 876. The Act allowed for the suspension of deportation where the person was needed to assist in the prosecution of immigration violators. Id. $\S 18,39$ Stat. at 888 .

${ }^{94}$ See id. $\$ 3,39$ Stat. at 878 .

${ }^{95}$ See Alien Registration Act of 1940, ch. 439, $\$ 20,54$ Stat. 670,672 (amending Act of Feb. $5,1917, \S 19,39$ Stat. at 889 ). The Alien Registration Act was primarily designed to deal with preventing the admission of persons suspected of engaging in subversive activities. See 86 Cong. Rec. 7818 (1940) ("The Committee of the Judiciary is very anxious to secure action on this measure, because it [will] assure the public that Congress is doing something about the so-called 'fifth column' and in correcting subversive activities.").

${ }^{96}$ Alien Registration Act of $1940 \$ 20,54$ Stat. at 672.

${ }^{97}$ Id.

${ }^{98}$ Id. 
tation statutes of the time. ${ }^{99}$ The clear effect of these deportations was the separation of families, which often meant that a family's sole wage earner would be removed from the country. ${ }^{100}$ In 1948, the law was amended further to permit suspension of deportation for those immigrants who could demonstrate the requisite hardship, but who did not have family ties with U.S. citizens or permanent residents. ${ }^{101}$

However, with the exception of amendments enacted in 1986, each amendment of the immigration laws since the 1948 statute has curtailed suspension relief. ${ }^{102}$ Amendments enacted in 1996 imposed further restrictions and renamed the benefit "cancellation of removal."103 Since its original establishment in 1940, Congress has progressively curtailed access to this benefit by increasing the level of hardship, complicating the procedure for qualifying, and most recently, requiring that the hardship not be on the applicant, but rather on her U.S. citizen family member instead. ${ }^{104}$

In addition to the good moral character basis for suspension of deportation, the 1948 amendments required a person to show continuous residence in the United States for seven years at the time that the application was submitted. ${ }^{105}$ The amendments modified Congress's role in the process by requiring both the House and Senate to pass favorable resolutions before the suspension would be effective. ${ }^{106}$ Following the 1948 amendments, two avenues for suspension relief were created: one for those who could demon-

\footnotetext{
${ }^{99}$ See GoRdon ET AL., supra note $13, \S 74.07(2)(a) \&$ n.4.

${ }^{100}$ Many of the earlier cases for this relief involved seamen who were married to U.S. citizens, traveled frequently, and did not have legal status in the United States. The economic hardship to a person's family was the standard for justifying a grant of lawful status in the form of suspension of deportation. See S. REP. No. 81-1515, at 595-96 (1950).

101 See Act of July 1, 1948, ch. 783, 62 Stat. 1206; S. REP. No. 81-1515, at 596.

${ }_{102}$ See, e.g., 8 U.S.C. $\$ 1254(\mathrm{~b})(2)$ (1994), repealed by Pub. L. No. 104-208, div. C, $\S 308(b)(7), 110$ Stat. 3009 (1996). The amendments enacted in 1986 were primarily focused on correcting the results of the Supreme Court's interpretation of the statute, which found that any absence for whatever period, irrespective of the reason, created a break in a person's continuous residence for purposes of qualifying for suspension of deportation. See Immigration \& Naturalization Serv. v. Phinpathya, 464 U.S. 183 (1984); H.R. REP. No. 99-682(I), at 78 (1986) as reprinted in 1986 U.S.C.C.A.N. 5649, 5682.

${ }^{103}$ In part, the re-characterization of the benefit to "cancellation of removal" served the purpose of conformance with the language of the 1996 statute, which replaced the term "deportation" with "removal." See AEDPA, Pub. L. 104-132, § 401, 110 Stat. 1214, 1258-68 (codified as amended in 8 U.S.C. $\$ \S 1531-37$ (2006)). The 1996 amendments also increased the level of requisite hardship, and required an applicant to show that "removal" would result in extremely exceptional and unusual hardship to his citizen or permanent resident spouse or children. See IIRAIRA, Pub. L. No. 104-208, div. C, sec. 304, § 240A(b)(7)(D), 110 Stat. $3009,3009-594$ (1996) (codified as amended at 8 U.S.C. $\$ 1229 b(b)(1)(D)(2006)$ ). The previous version had required only extreme hardship on the alien or his U.S. citizen or permanent resident spouse and children. See 8 U.S.C. $§ 1254($ a)(1) (1994) (repealed 1996).

${ }^{104}$ Indeed, much of the critique leveled at suspension of deportation in the post-1962 period was related to its illusory nature. See Comment, Suspension of Deportation: Illusory Relief, 14 San Diego L. REv. 229 (1976).

${ }^{105} 62$ Stat. at 1206.

${ }^{106}$ See id.
} 
strate five years of good moral character and economic hardship, and the second for those able to prove seven years of continuous residency. ${ }^{107}$

Four years later, with the enactment of the century's most comprehensive immigration reform, Congress further modified the suspension relief through the McCarran-Walter Act. ${ }^{108}$ The 1952 revisions were based on the belief that there had been a widespread pattern of abuse in suspension claims and that the relief needed to be curtailed. ${ }^{109}$ The result was that suspension of deportation was modified to require a showing of good moral character, continuous residency, and that the person's deportation would result in exceptional and extremely unusual hardship to the applicant or her immediate family members. ${ }^{110}$ The statute broke down suspension applicants into five different classes based on the grounds of deportability that would be suspended, with different residency requirements for each. ${ }^{11}$ Depending on the basis for deportability, the suspension claim could either require a positive resolution or inaction in both houses of Congress. ${ }^{112}$ While Congress accomplished its objective of severely limiting suspension relief, the numbers of private bills increased substantially. ${ }^{113}$ In the end, Congress, in its effort to limit the suspension relief, created a very confusing set of laws. ${ }^{114}$

Later amendments to suspension relief occurred in 1962 and 1996. In the 1962 amendments, Congress significantly simplified suspension of deportation relief, ${ }^{115}$ which, as noted, had become complicated by the 1952

\section{${ }^{107}$ See id.}

${ }^{108}$ Ch. 477, 66 Stat. 163 (1952) (codified as amended in scattered sections of 8 U.S.C.). The process began in 1947, culminating in an extensive report issued in 1950 titled "The Immigration and Naturalization Systems of the United States." S. REP. No. 81-1515 (1950).

${ }^{109}$ See S. REP. No. 81-1515, at 556, 595-603.

${ }^{110}$ McCarran-Walter Act $\S 244,66$ Stat. at 214-16.

111 Id.

${ }^{112}$ Id. at 216. For example, if the basis for deportability was $\mathrm{X}$, a positive resolution was required, whereas if the basis was $\mathrm{Y}$, then relief would only be precluded by the introduction of a negative resolution.

113 See Comment, Suspension of Deportation-A Look at the Benevolent Aspect of the McCarran-Walter Act, 61 Mich. L. REv. 352, 369 (1962). Private bills are those introduced by members of Congress to grant special dispensation, often in the form of permanent residency, something not otherwise available under the statute. While few conclusions can be drawn about private bills without conducting an exhaustive exploration of each bill, commentators agree that private immigration legislation is representative of some of the compelling humanitarian cases that individual members of Congress receive from their constituents. See GALLagher, supra note 21, at 7; SANa Loue, Immigration Law and Health $\$ 8.1$ (2009); Kati Griffith, Perfecting Public Immigration Legislation: Private Immigration Bills and Deportable Lawful Permanent Residents, 18 GEo. IMMIGR. L.J. 273-80 (2004). According to records kept by the Department of Homeland Security, the number of introduced private bills began increasing dramatically in the 80th Congress $(1947-48)$ and reached its peak in the 85 th Congress (1957-58), around the same time as when Congress moved the registry date to 1940 . See Office of Immigration Statistics, U.S. Dep't of Homeland Sec., 2003 Yearbook of ImMIGRATION STATISTICS 182 tbl.51 (2004). Statistics on the introduction and enactment of private bills are not available before the 77 th Congress $(1941-42)$.

114 See Gordon, supra note 13, \$ 74.07[2][b]; President's Comm'N on IMmigration and Naturalization, Whom We Shall Welcome 211 (1953).

115 See Act of Oct. 24, 1962, Pub. L. No. 87-885, § 4, 76 Stat. 1247, 1247-49 (repealed 1996). 
enactment of the McCarran-Walter Act. The 1962 changes retained the legislative veto and reduced the classes of suspension from five to two. ${ }^{116}$ The amendments enacted in 1996 brought about another shift from earlier laws and were part of a larger reformulation of the immigration laws. ${ }^{117}$ With the 1996 amendments, Congress created one unified "removal" procedure in place of the exclusion/deportation proceedings found in the earlier immigration laws. ${ }^{118}$

With the enactment of the 1996 amendments, what had previously been known as "suspension of deportation" became known as "cancellation of removal." 119 Since the amendments were not retroactive, the narrower 1996 prerequisites for cancellation were not imposed on those who had already met the requirements of the previous suspension of deportation. ${ }^{120}$ The statute created two broad categories of cancellation: one for permanent residents, ${ }^{121}$ acting as a waiver on grounds of inadmissibility and deportability, and one similar to the earlier suspension of deportation, but only available to those who are not permanent residents. ${ }^{122}$ The 1996 amendments also placed

${ }^{116} I d$. at 1247-48. Suspension applicants who were deportable based on most grounds found in the statute were required to show: (1) extreme hardship to either themselves or their immediate family members who were permanent residents or U.S. citizens; (2) good moral character; and (3) seven years of continuous residency. Id. Those deportable for certain crimes were expected to show extremely exceptional and unusual hardship and good moral character for ten years following the act constituting the criminal basis for deportability. Id. at 1248 . The legislative veto provisions would later be found unconstitutional in Immigration \& Naturalization Serv. v. Chadha, 462 U.S. 919, 959 (1983). According to some commentators, the only effective legislative veto would be one that was enacted through the normal legislative process, meaning passage by both chambers of Congress and presentation to the President for approval or veto. See Ronald D. Rotunda \& John E. Nowak, 2 Treatise on Constitutional. Law-Substance \& Procedure $\S 10.8$ (b) (4th ed. 2007).

117 See IIRAIRA, Pub. L. No. 104-208, 110 Stat. 3009 (1996) (codified as amended in scattered titles of U.S.C.).

${ }^{118} \mathrm{Id}$.

${ }^{119}$ Id. at div. C, sec. $304, \S 240 \mathrm{~A}, 110$ Stat. at 3009-594 (codified as amended at 8 U.S.C. $\S 1229$ b (2006)).

${ }_{120}$ The passage of the 1996 amendments provided the impetus for additional relief from the changes made to suspension/cancellation relief. In 1997, Congress passed legislation that extended the less onerous hardship standards, which had existed prior to the 1996 amendments, to certain nationals of Nicaragua, Cuba, El Salvador, and Guatemala, nationals of former Soviet bloc countries, and their dependents. See Nicaraguan Adjustment and Central American Relief Act ("NACARA"), Pub. L. No. 105-100, tit. II, § 203, 111 Stat. 2160, 2196 (1997) (codified as amended in 8 U.S.C. $\$ 1101$ (2006 \& Supp. II 2008)). Those who were eligible to apply would only need to show extreme hardship to themselves or their U.S. citizen or permanent resident family members as opposed to extremely exceptional and unusual hardship to their U.S. citizen or permanent resident family members.

121 IIRAIRA, div. C, sec. 304, \$240A(a), 110 Stat. at 3009-594 (codified as amended at 8 U.S.C $\& 1229$ b(a) (2008)). It replaced what was previously known as "212(c)" relief.

${ }^{122}$ Id. $\S 240 \mathrm{~A}(\mathrm{~b})$ (codified as amended at 8 U.S.C $\S 1229 \mathrm{~b}(\mathrm{~b})$ ). The special form of cancellation relief that is available to battered spouses, parents, or children of U.S. citizens or permanent residents under $\S 1229 \mathrm{~b}(\mathrm{~b})(2)$ is not included in this discussion. See 8 U.S.C. $\S 1229 \mathrm{~b}(\mathrm{~b})(2)$. This form of cancellation is more generous than the previous suspension of deportation as it is available to persons who were never married, but intended to marry, a lawful permanent resident or citizen and were subject to extreme cruelty. Id. $\S 1229 \mathrm{~b}(\mathrm{~b})(2)(\mathrm{A})(\mathrm{i})(\mathrm{III})$. Normally, under immigration law, the non-citizen beneficiary must have a petitioning spouse, parent, or family member. This form of cancellation eliminates the 
the first numerical cap on the number of suspension applicants who could be adjusted to permanent residency in any given year. ${ }^{123}$ Further, the amendments required ten years of continuous residency and hardship of an exceptional and extremely unusual nature to the applicant's immediate family. ${ }^{124}$

Prior to the 1996 amendments, under suspension of deportation, a person's absences which were "brief, casual, and innocent and did not meaningfully interrupt" her physical presence would not have led to disqualification from relief. ${ }^{25}$ However, under the current cancellation of removal system, an absence is treated as a break in the person's residence if she has been out of the country for more than ninety days on an individual trip or in excess of 180 days in the aggregate. ${ }^{126}$ The newly created cancellation, unlike the previous suspension of deportation, is also available to persons in removal proceedings where they are seeking admission. ${ }^{27}$ The 1996 amendments retained the good moral character requirements and extended the requirements to the ten-year period immediately preceding the filing of the application. ${ }^{128}$ Finally, under the 1996 amendments, broad categories of people are ineligible for cancellation of removal, including persons who were admitted as crewmen subsequent to June 30,1964 , certain exchange visitors, persons inadmissible or deportable on security grounds, and those immigrants previously granted cancellation relief. ${ }^{129}$

While the available data on suspension of deportation are difficult to evaluate due to variations in reporting and changes in the procedure for approval, the period from 1940 to 1947 appears to have been the most favorable for the applicant. ${ }^{130}$ In these years, an average of nearly 3000 applications were granted per year. ${ }^{131}$ In only one year between 1948 and 1986 did the number of approvals reach close to the average of the first seven

petition requirement by the abuser. See 8 C.F.R. $\$ 204.2$ (c)(4) (2008) (allowing self-petition by spouse of abusive citizen or lawful permanent resident).

${ }^{123}$ IIRAIRA, div. C, sec. 304, $\$ 240 \mathrm{~A}(\mathrm{e}), 110$ Stat. at 3009-596 (codified as amended at 8 U.S.C $\$ 1229 \mathrm{~b}(\mathrm{e})(1))$. No more than 4000 applicants could be adjusted under the statute. Id.

${ }_{124}$ See id. $\$ 240 \mathrm{~A}(\mathrm{~b})(1), 110$ Stat. at $3009-594$ (codified as amended at 8 U.S.C. $\S 1229 \mathrm{~b}(\mathrm{~b})(1))$. Under previous versions of suspension of deportation, a person could base her claim on hardship to herself in addition to the hardship on his or her family members. See 8 U.S.C. $\$ 1254($ a)(1) (1990) (repealed 1996).

1258 U.S.C. $\$ 1254(\mathrm{~b})(2)$.

${ }^{126}$ IIRAIRA, div. C, sec. $304, \S 240 \mathrm{~A}$ (d)(2), 110 Stat. at 3009-595 (codified as amended at 8 U.S.C $\S 1229 \mathrm{~b}(\mathrm{~d})(2)(2006))$.

${ }^{127}$ Id. $\S 240 \mathrm{~A}(\mathrm{~b}), 110$ Stat. at $3009-594$ (codified as amended at 8 U.S.C. $\S 1229 \mathrm{~b}(\mathrm{~b})(1)$ (2006)).

${ }^{128} \mathrm{Id}$ (2006))

${ }^{129}$ Id. $\S 240 \mathrm{~A}(\mathrm{c}), 110$ Stat. at $3009-595$ (codified as amended at 8 U.S.C. $\S 1229 \mathrm{~b}(\mathrm{c})$

${ }^{130}$ According to the agency's annual reports during the period from 1940 to $1947,20,444$ cases were submitted for approval to Congress. However, it is not clear how many cases were rejected. See Immigration \& Naturalization Serv., U.S. Dep't of Justice, Annual RePORT OF THE IMMIGRATION AND Naturalization SERvice (1947). As noted previously, until 1948 , a person would receive permanent residency unless a negative resolution was introduced in both houses of Congress.

${ }^{131}$ Id. 
years of the suspension statute. ${ }^{132}$ Otherwise, the highest number of approvals was 1088 in 1956, and in many years it was barely over 100 persons. ${ }^{133}$ In the five-year period immediately preceding the enactment of the amnesty of 1986, a total of 835 people were granted relief. ${ }^{134}$

\section{The AMNESTy OF 1986}

There were many reasons for enacting an amnesty in 1986. First, the grant of an amnesty would provide political cover for the employer sanctions that were to be imposed as part of the immigration legislation. ${ }^{135}$ Second, the millions of undocumented persons who were in the country at the time could not have been removed without a major strain on the immigration enforcement system. ${ }^{136}$ Third, many of these people had built substantial ties within their communities and were contributing to them in a valuable way.

In enacting the 1986 reforms, Congress effectively created two different amnesty programs: one for agricultural workers, and the other for un-

${ }^{132}$ In the fiscal year ending on June 30, 1952, 7300 cases had been submitted and 2899 were approved. See Immigration \& Naturalization Serv., U.S. Dep't of Justice, Annual Report of the Immigration and Naturalization Service 30 (1952).

${ }^{133}$ For example, in 1963 and 1964, the number of approvals was 20 and 15 , respectively, and in 1970, 1975, and 1980 it was, respectively, 199, 121, and 17. See IMMIGRATION \& Naturalization Serv., U.S. Dep't Of Justice, 1980 Statistical Yearbook of the Immigration and Naturalization Service 7-10 tbl.4; Immigration \& Naturalization Serv., U.S. Dep't of Justice, Annual Report of the Immigration and Naturalization Service 1975 34; Immigration \& Naturalization Serv., U.S. Dep'T of Justice, AnNual Report of THE IMmigration and Naturalization SERvice 1970 38; 1965 Immigration Report, supra note 54 , at 25 .

${ }^{134}$ Immigration \& Naturalization Serv., U.S. Dep't of Justice, 1985 Statistical Yearbook of the ImMigration and Naturalization Service 12 (1986). The suspension of deportation cases for 1986 was not incorporated because the 1986 amnesty, with its primary prerequisite of unauthorized status for four years preceding its enactment, provided suspension applicants with a more viable form of relief.

${ }^{135}$ Indeed, a refrain that would be repeated in the Hesburgh Commission was that the amnesty, together with sanctions, would effectively close the "back-door" of immigration by taking away the incentive to migrate to work in the United States. See SELECT COMM'N ON Immigration \& Refugee Policy, U.S. Immigration Policy and the National Interest, The Final Report and Recommendations of the Select Commission on Immigration and Refugee Policy to the Congress and the President of the United States 3 (1981), available at http://www.eric.ed.gov/ERICWebPortal/contentdelivery/servlet/ERICServlet? accno $=$ ed211612. The Commission indicated that " $[t]$ he recommended legalization program will help to enforce the law, however, only if other enforcement measures designed to curtail future illegal migration to the United States are instituted." Id. at 14. Thus, "[r]ecognizing that future migration pressures could lead to even higher levels of illegal migration to the United States, [they] emphasized the development of effective enforcement strategies, including a new law to penalize employers who hire undocumented/illegal aliens and new measures to control the abuse of non-immigrant status." Id.

136 The Hesburgh Commission considered a variety of programs to solve the problem of a large undocumented alien population, including massive deportation and legalization, and concluded that "[a]ttempts at massive deportation would be destructive of U.S. liberties, costly, likely to be challenged in the courts and, in the end, ineffective." Id. at 72-73. Indeed, the only massive deportation effort in U.S. history occurred in the mid-1950s with tremendous monetary and personnel costs and civil liberty violations of those expelled or repatriated by the Immigration and Naturalization Service. Id. at 73. 
documented persons who were not connected to the agricultural industry. ${ }^{137}$ The major difference between these two programs was that the agricultural worker provisions had fewer and less rigid requirements. For example, while non-agricultural workers were required to show unlawful status prior to January $1,1982,{ }^{138}$ the "agricultural workers" needed to show only that they had worked for at least ninety days during the period between May 1, 1985 and May 1, 1986. ${ }^{139}$ Agricultural workers could apply for amnesty up to eighteen months after the period beginning seven months following the statute's enactment, ${ }^{140}$ while the non-agricultural workers were required to file for amnesty within twelve months beginning not later than six months following the enactment date. ${ }^{141}$

The differences between the two amnesty schemes can only be justified as part of the political compromise needed to secure the bill's passage, given the important agricultural interests in Congress. ${ }^{142}$ There was great concern that increased border enforcement and sanctions against employers who would later hire unauthorized workers would create difficulties for these employers in securing the workers needed to harvest crops and perform other functions on the farms each season. ${ }^{143}$ The compromise included additional

${ }^{137}$ See IRCA, Pub. L. No. 99-603, secs. 201, 302, 100 Stat. 3359 (codified as amended at 8 U.S.C. $\$ \S 1160(\mathrm{a}), 1255 \mathrm{a}(\mathrm{a})(2006)$ ) (section $1160(\mathrm{a})$ is entitled "Special Agricultural Workers").

${ }_{138} \mathrm{Id}$. at sec. $201, \S 245 \mathrm{~A}(\mathrm{a})(2)(\mathrm{A}), 100$ Stat. at 3394 (codified as amended at 8 U.S.C. $\S 1255 \mathrm{a}(\mathrm{a})(2)(\mathrm{A}))$.

${ }^{139}$ Id. at sec. 302(a), $\$ 210(\mathrm{a})(1)(\mathrm{B}), 100$ Stat. at 3417 (codified as amended at 8 U.S.C. $\S 1160(\mathrm{a})(1)(\mathrm{B}))$. While not essential to this discussion, there were two groups of agricultural workers under the statute: one that was called "group 1" and consisted of the first 350,000 qualifying applicants, and "group 2," which was the remainder of those qualifying for amnesty. Id. $\S 210(\mathrm{a})(2), 100$ Stat. at $3417-18$ (codified as amended at 8 U.S.C. $\$ 1160(\mathrm{a})(2)$ ). Group 1 members were first accorded temporary residence and, one year later, received permanent residency, while group 2 members received temporary residency, but had their adjustments to permanent residency delayed until one year after the end of the application period. Id.

${ }^{140} \mathrm{Id}$. at sec. $302, \S 210(\mathrm{a})(1)(\mathrm{A}), 100$ Stat. at 3417 (codified as amended at 8 U.S.C. $\S 1160(\mathrm{a})(1)(\mathrm{A}))$.

${ }^{141} \mathrm{Id}$. at sec. $201, \S 245(\mathrm{a})(\mathrm{I})(\mathrm{A}), 100$ Stat. at 3494 (codified as amended at 8 U.S.C. $\S 1255 \mathrm{a}(\mathrm{a})(1)(\mathrm{A}))$.

${ }_{142}$ See, e.g., 131 Cong. Rec. 23,579 (1985) (Sen. Orrin Hatch (R-Utah) noted, "[t]his country cannot afford to attempt immigration reform, while ignoring the vital interests of small farmers who produce our agricultural necessities," and Sen. Alan Simpson (R-Wyo.) stated that "I could not agree with my colleagues more that agriculture, especially perishable commodities, has some very special needs. . . [M] any of the things that we depend on in this country [are] in agriculture").

${ }^{143}$ See, e.g., id. at 23,576 (Sen. Pete Wilson (R-Cal.) stated that the "purpose of [the] amendment is to provide a seasonal agricultural worker program for employment in perishable commodities, the objective of which is consistent with those desired by the supporters of this immigration reform legislation"). In addition to providing the amnesty programs, the statute for the first time included provisions that imposed civil fines and possible criminal penalties on employers who knowingly hired unauthorized workers. See IRCA, Pub. L. No. 99-603, sec. 101, 100 Stat. 3359, 3360-74 (1986) (codified as amended at 8 U.S.C. \$ 1324a(e)-(f) (2006)). The statute further imposed a requirement that all employers conduct at least a cursory document verification or check of persons whom they hire within three days of employment. Id. at sec. $101, \S 274 \mathrm{~A}(\mathrm{~b}), 100$ Stat. at $3361-63$ (codified as amended at $\S 1324 \mathrm{a}(\mathrm{b})$ ). 
"sweeteners," such as restrictions on farm searches, ${ }^{144}$ and other provisions designed to facilitate the admission of temporary foreign agricultural workers in future years. ${ }^{145}$ The inclusion of the anti-discrimination amendments secured additional support for the bill's passage. ${ }^{146}$ These amendments were designed to allay concerns that employer sanctions would cause discrimination against persons whom employers might believe were unauthorized workers. ${ }^{147}$

The non-agricultural amnesty program required that the applicant show that he had been in the United States before January 1, 1982 and that she had resided continuously in an unlawful status from January 1, 1982 until the application was filed. ${ }^{148}$ The provision also precluded amnesty: (1) where the person had been convicted of any felony or three or more misdemeanors committed in the United States; (2) where she had participated in the persecution of others; or (3) where she was inadmissible because of a narcotics conviction or due to political or security grounds. ${ }^{149}$ Under the regulations promulgated pursuant to the statute, brief, casual, and innocent trips would not be treated as breaks in a person's residence, unless an individual trip exceeded forty-five days or the trips totaled more than 180 days after January 1, 1982. ${ }^{150}$ Similarly, pre-authorized emergency trips, or those with a humanitarian purpose would not be regarded as breaks in residence. ${ }^{151}$

Under the new program, the applicant for amnesty was in the peculiar position of proving illegal status or simple entry, because a legal entry would disqualify the person from eligibility for the benefit. For example, a person who entered the country legally might be able to argue that she was in the United States illegally either because she had remained longer than authorized or because of a failure to file regular address report changes with the

${ }^{144}$ See IRCA, sec. $116, \S 287$ (d), 100 Stat. 3359,3384 (codified as amended at 8 U.S.C. $\S 1357(\mathrm{e})(2006))$.

${ }^{145}$ See id. at sec. 301,100 Stat. at 3411-17 (codified as amended at 8 U.S.C. $\S 1101(\mathrm{a})(15)(\mathrm{H})(\mathrm{ii})(\mathrm{a})(2006)$ ) which provides for the temporary admission of agricultural workers as defined by the Secretary of Labor. This program is commonly known as the $\mathrm{H}-2 \mathrm{~A}$ program. See EsSENTIALS OF IMMIGRATION LAw, supra note 14, at 115-16.

${ }^{146}$ IRCA, sec. $201, \S 245$ A, 100 Stat. 3359 (codified as amended at 8 U.S.C. $\$ 1324 a(j)$ (repealed 1996))

${ }^{147}$ See, e.g., 132 Cong. REc. 30,905 (1986). The bill's requirement that employers verify all workers was intended in part to avoid possible discrimination.

${ }^{148}$ See IRCA, sec. $201, \& 245 \mathrm{~A}(\mathrm{a})(2)(\mathrm{A}), 100$ Stat. at 3359 (codified as amended at 8 U.S.C. $\S 1255 \mathrm{a}(\mathrm{a})(2)(\mathrm{A})(2006))$.

${ }_{149}$ See id. at sec. 201, § 245A(a)(4), 100 Stat, at 3395 (1986) (codified as amended at 8 U.S.C. $\$ 1255 \mathrm{a}(\mathrm{a})(4)(2006)$ ). Excepted from this are convictions for possession of less than thirty grams of marijuana. Id. $\S 245 \mathrm{~A}$ (d)(2)(B)(ii)(III), 100 Stat. at 3399 (codified as amended at 8 U.S.C. $\S 1255 \mathrm{a}(\mathrm{d})(2)(\mathrm{B})(\mathrm{ii})(\mathrm{II})(2006)$ ).

${ }^{150}$ Id. $\$ 245 \mathrm{~A}(\mathrm{a})(3), 100$ Stat. at 3395 (codified as amended at 8 U.S.C. $\S 1255 \mathrm{a}(\mathrm{a})$ (2006)). The standard for determining whether the break actually interrupted the person's continuous residency requires a showing that the absence was not brief or casual. Id. $\S 245 \mathrm{~A}(\mathrm{~g})(2)(\mathrm{A}), 100$ Stat. at 3400 (codified as amended at 8 U.S.C. $\S 1255 \mathrm{a}(\mathrm{g})(2)(\mathrm{A})$ (2006)).

${ }^{151} 8$ C.F.R. $\S 245 a .2(i)(2008)$. 
government, but this person would not be eligible for amnesty. ${ }^{152}$ A person who entered the country on a tourist visa, worked in the United States, obtained a social security card, and filed tax returns-acts that were treated as making the unlawful status known to the government-would be similarly ineligible for the benefit. ${ }^{153}$ Thus, the exercise of establishing illegal status could be successful even if the person was only able to establish technical violations of her status.

There has, and continues to be, litigation in cases involving this amnesty program. ${ }^{154}$ The requirement that an applicant establish continuous residency caused many people returning from brief overseas trips during the amnesty period to be rejected when they originally sought amnesty because the INS required that government employees or representatives of agencies that were authorized to receive amnesty applications reject applications containing such a break in residency. ${ }^{155}$ Other cases involved persons who were illegally in the United States before January 1, 1982 and re-entered with fraudulent visas. ${ }^{156} \mathrm{~A}$ number of these cases are still pending, and final adjudication on the legalization applications is ongoing as part of the settlement reached between the government and the parties in the case. ${ }^{157}$

\section{Registry, Suspension, and Cancellation as AMnEsty Surrogates}

The underlying purpose of any amnesty is to grant the beneficiary a form of permanent or durable legal status in the United States. The legal mechanisms, or immigration relief, that have been used to accord this status are registry, suspension of deportation (cancellation of removal), and private legislation. As noted, private legislation is an extraordinary remedy when all

${ }^{152}$ See In re H-, 20 I. \& N. Dec. 693, 696 (B.I.A. 1993) (presenting a situation where applicant had failed to comply with the address notification and regular reporting requirement under 8 U.S.C. $\$ 1305$ (1976) for non-immigrants), rev'd on other grounds, Immigrant Assistance Project v. Immigration \& Naturalization Serv., 306 F.3d 842 (9th Cir. 2002).

${ }^{153}$ In re P-, 19 I. \& N. Dec. 823, 826, 829 (B.I.A. 1988). One way that a person could qualify for temporary resident status was where the person fell out of status and that fact became "known to the government." 8 C.F.R. § 245a.1(d) (2006).

${ }^{154}$ See, e.g., Immigrant Assistance Project of the L.A. City. Fed. of Labor (AFL-CIO) v. Ashcroft, 306 F.3d 842 (9th Cir. 2002); Catholic Soc. Servs. v. Immigration \& Naturalization Serv., 232 F.3d 1139 (9th Cir. 2000) (en banc), remanded to Catholic Soc. Servs., Inc. v. Ashcroft, 206 F.R.D. 654 (E.D. Cal. 2002); Catholic Soc. Servs. v. Meese, 685 F. Supp. 1149 (E.D. Cal. 1988), aff'd sub nom. Catholic Soc. Servs. v. Thornburgh, 956 F.2d 914 (9th Cir. 1992), vacated sub nom. Reno v. Catholic Soc. Servs., 509 U.S. 43 (1993), remanded sub nom. Lopez v. Mukasey, 241 Fed. Appx. 958 (4th Cir. 2008), cert. denied, 129 S. Ct. 447 (2008).

${ }^{155}$ See Catholic Soc. Servs., 232 F.3d at 1142-43; Catholic Soc. Servs., 685 F. Supp. 1149 (E.D. Cal. 1988).

${ }^{156}$ In re P-, 19 I. \& N. Dec. 823, 827-28 (B.I.A. 1988).

157 The settlement allowed the applicants to re-submit their legalization claims. The cases would be re-adjudicated, with the applicant's right to appeal preserved. See Courts Approve Settlement Agreements in LULAC/Newman, CSS; Filing Instructions Expected at End of March, 81 INTERPRETER RELEASES 275, 275-77 (2004). 
other forms are unsuccessful. ${ }^{158}$ All of these remedies are designed to ameliorate the severe hardships that restrictive immigration laws can impose upon an applicant's family and community. While each of these forms of relief may not require proof of each of the elements described here, each does contemplate that the undocumented person has spent some extended period of time living in and becoming a part of the community, and that to force her removal would be seen as an unnecessary hardship.

Registry and suspension relief have provided mechanisms for dealing with the dilemma of having provisions in the law that require the deportation of persons, while simultaneously giving the adjudicator discretion to ameliorate the hardships of separating the applicant from her well-established roots in the community. Without these discretionary devices, the government would ultimately be required to take large numbers of undocumented persons and place them into the removal process, which would burden the system with time and resource consuming adjudications. Certainly, at least some people believe that deporting much of the undocumented population is the appropriate solution. ${ }^{159}$ However, forcing the immigrants' departure is contrary to the principles of family unity and humanitarianism, which have long been important elements of our immigration policy. The longer that a person lives and works in the community, the more difficult and wrenching her separation will be. While those hardships will fall heaviest on families that are comprised of U.S. citizens and permanent residents, separation will also cause hardships to others including businesses, churches, and other social groups within the community. Indeed, because of the legal obstacles created in 1996, unless significant amendments are made to the immigration laws as part of a broad-based amnesty program, forced deportations will cause the permanent separation of immigrants from their communities and families.

While registry is similar to amnesty, it differs from the 1986 amnesty in several ways. Unlike registry, which accords permanent residency on its beneficiaries, the 1986 amnesty granted temporary status to applicants. ${ }^{160}$ This temporary status did not enable the beneficiary to confer derivative or any other status on immediate family members. ${ }^{161}$ One year after receiving temporary residence, the amnesty recipient could apply for permanent resi-

158 See GALLAGHER, supra note 21 , at 12.

${ }^{159}$ See Immigration Reform Dead, Ariz. REP., June 29, 2007, at A.1; Carolyn Lochhead, House GOP Doing it their Own Way on Immigration, S.F. Chron., Jun. 21, 2006, at A.5.

${ }^{160}$ See IRCA, Pub. L. No. 99-603, sec. 201, § 245A(a), 100 Stat. 3359, 3394-95 (1986) (codified as amended at 8 U.S.C. $\$ 1255 \mathrm{a}(\mathrm{a})(2006)$ ).

${ }^{161}$ Normally in immigration law, there is a primary beneficiary (the main applicant) and derivative beneficiaries (the applicant's immediate family). For example, many nonimmigrant visas allow accompanying immediate family members to acquire the same visa classification. See, e.g., 8 U.S.C. \$ $1101(\mathrm{a})(15)(\mathrm{F})(\mathrm{ii})(2006)$ (student visas); $\S 1101(\mathrm{a})(15)(\mathrm{G})(\mathrm{i})(2006)$ (government officials); $\S 1101(\mathrm{a})(15)(\mathrm{H})(\mathrm{iii})(2006)$ (temporary work visas). Immigrant visas are issued in a similar fashion. See Essentials of IMmigration LAw, supra note 14, at 98. While this has been the practice in most areas of immigration law, Congress did not follow this approach was not followed when it created the amnesty in 1986. IRCA, sec. 201, § 245A(a). 
dent status. ${ }^{162}$ Only after receiving this status could he petition for family members and begin to accrue status in order to apply for citizenship. ${ }^{163}$

This status restriction created serious problems for those who qualified for the 1986 amnesty, as their family members remained unprotected. It would not be until many years later that those family members would be able to obtain legal status. ${ }^{164}$ In some cases, family members were placed into complicated immigration quandaries resulting in even more burdens on the immigration system. Indeed, as mentioned previously, a number of those who were unable to obtain amnesty have remained in the country only to seek other immigration relief.

The following scenario illustrates a few of the problems that resulted as a consequence of the limits placed on 1986 amnesty recipients. Imagine that an undocumented person, $A$, has been in the United States illegally since before the amnesty cutoff date of January 1, 1982, but her spouse and immediate family members enter the United States illegally on a later date. Even if A could qualify for amnesty, her family members will remain "illegal" for years beyond the time that A qualifies for the amnesty. Oftentimes, A's family members will be required to leave the United States and return to their native country, because the amnesty legislation requires that each individual family member be able to separately qualify for relief. If a family member is discovered before obtaining legal status, she remains subject to the deportation process.

A person may petition for her spouse and unmarried children only if she is either a lawful permanent resident or a U.S. citizen. ${ }^{165}$ While the process for a citizen petitioning for a spouse or child is significantly faster than when the petitioner is a permanent resident, it remains quite lengthy. ${ }^{166}$ Under the amnesty program, an application to confer status on behalf of a family member can be filed only after the primary beneficiary secures status, not when legalization is granted. ${ }^{167}$ More importantly, the immigrant quota restrictions prevent the immediate family member from receiving status until

${ }^{162}$ See IRCA, sec. 201, § 245A(b), 100 Stat. at 3395-97 (codified as amended at 8 U.S.C. $\S 1255 \mathrm{a}(\mathrm{b})(2006))$.

${ }^{163}$ The general qualifying period for naturalization (citizenship) is five years unless the person acquired his permanent residency based on marriage to a U.S. citizen or has served honorably in the military under a declared hostility. See 8 U.S.C. $\S \S 1427$ (a)(1), 1430(a) (2006).

${ }^{164}$ A person without permanent legal status may not petition for family members until his status becomes permanent, at which time he remains subject to the immigrant quota. See EsSENTIALS OF IMMIGRATION LAW, supra note 14, at 129, 133.

${ }^{165} \mathrm{Id}$. at 133 .

${ }^{166} \mathrm{Id}$. at $135-36$. When a citizen is petitioning for her immediate family member, she proceeds outside of the immigration quota. If she entered with a visa, she may be able to obtain status without leaving the country through a process called "adjustment of status." See 8 U.S.C. $\$ 1255$ (a) (2006). The immediate family is defined as the spouse and minor children or, in the case of an adult petitioner, and it can include the parents of the U.S. citizen where the child is 21 or older. See id. $\S 1151$ (b)(2)(A)(i) (2006).

${ }^{167}$ See 8 U.S.C. $\S 1255$ (2006 \& Supp. II 2008). 
the quota restrictions have been satisfied. ${ }^{168}$ Other restrictions in 8 U.S.C. $\S 1255$ preclude a person from obtaining permanent residency until after she departs the United States and proceeds to an overseas U.S. Consulate to receive an immigrant visa. ${ }^{169}$ These hardships that were visited upon the other non-qualifying family members resulted in Congress's 1990 enactment of the family unification provisions, which effectively provided a reprieve from deportation. ${ }^{170}$

The most recent failed attempt to enact amnesty legislation involved a statutory scheme that met only a few of the principles outlined in this Article. ${ }^{171}$ The version of amnesty that was passed by the Senate divided the potential beneficiaries into two broad categories: agricultural and non-agricultural workers. The proposal would have allowed an undocumented worker to obtain status after she had shown that she had been physically present in the United States before April 5, 2001 in an illegal status, had shown that she did not qualify under 8 U.S.C. $\$ 1182(a),{ }^{172}$ unless she could qualify for a waiver of the inadmissibility ground, and had paid a fine. ${ }^{173}$ The person would also have to show that she had been employed for at least three years during the five-year period from April 5, 2001 to April 5,

\footnotetext{
${ }^{168}$ Annual limitations on the spouses and unmarried children of lawful permanent residents are restricted to approximately 114,000 immigrants per year. Id. \$1153(a)(2) (2006).

169 The statute specifically prevents the adjustment of status to lawful permanent resident status where the person seeking the status has entered the United States without a visa or has worked without authorization, unless the petitioner is an immediate relative to a primary applicant. See id. $\S 1255$ (c) (2006).

${ }^{170}$ See IMMACT 90, Pub. L. No. 101-649, § 301, 104 Stat. 4978, 5029-30 (codified as amended at 8 U.S.C. $\S 1255$ a (2006 \& Supp. II 2008)); 136 CoNG. Rec. 27,072 (1990). Under the Family Unity Act, the spouse and unmarried children received an automatic stay of removal. IMMACT $90 \S 111$, 104 Stat. at 4986 . The family relationship must have been established by May 5, 1988 if the applicant applied under the non-agricultural amnesty, and December 1, 1988 if she applied under the provision for agricultural workers. See 8 C.F.R. $\$ 236.12$ (a)(2) (2007). The person would lose the benefits of family unity if, as the son or daughter, he or she was married, or if the spouse divorced the primary amnesty beneficiary. Id. $\S 236.18$. But see Hernandez v. Reno, 91 F.3d 776, 780-81 (5th Cir. 1996) (holding that, to receive status under family unity, the children of the legalized alien must be unmarried as of May 5, 1988 but need not remain unmarried after that date to continue to receive status). Congress, acknowledging that "[ $t]$ he wait for family reunification can be long and painful," included the Family Unity provisions in IRCA to help unite families. 136 Cong. ReC. 27,072 (statement of Rep. David Bonior (D-Mich.)). It recognized that it is not only "antifamily to allow such long separations [but] also counterproductive [as] it encourages illegal immigration as the best way to become united with loved ones." Id. Thus, its purpose was "to allow husbands and wives, and parents, and children to remain together [and] keep [the government] from wasting valuable enforcement resources on deporting children and spouses who will ultimately be allowed to enter the country anyway." 136 CONG. REC. 27,081 (statement of Rep. Bruce Morrison (D-Conn.)).

${ }^{171}$ The proposed legislation was part of the Comprehensive Immigration Reform Act of 2006 and included a title described as the Immigrant Accountability Act of 2006. S. 2611, 109th Cong. (2006).

${ }^{172}$ Section 1182(a) disallows immigrants from receiving visas based on, among other things, health-related grounds, criminal grounds, security-related grounds, and foreign policy grounds. 8 U.S.C. $\S 1182$ (a) (2006, Supp. I 2007, Supp. II 2008).

${ }^{173}$ S. $2611 \S 601($ b).
} 
2006. ${ }^{174}$ However, the employment requirement was modified depending on the person's physical or mental condition or educational level. ${ }^{175}$ In addition, the person was required to show that she had certain basic "citizenship skills" relating to English proficiency and knowledge of U.S. history and government. ${ }^{176}$

A similar bill was introduced in the House of Representatives, but it included a different cutoff date of June 1, 2006, ${ }^{177}$ and required a shorter employment period. ${ }^{178}$ Under the House's version, the applicant could satisfy the citizenship skill requirement by pursuing a course of study. ${ }^{179}$ According to the Senate bill, an agricultural worker could qualify for status if she had worked for an established number of hours in the two-year period ending on December 31, 2005. 180 The House version had the same employment requirement, but it covered the two-year period ending December 31, 2006. ${ }^{181}$ Neither version included a citizenship skills requirement for agricultural workers. ${ }^{182}$

By some accounts, the number of undocumented persons in the United States approaches eleven million. ${ }^{183}$ Any amnesty program will significantly tax the resources of whichever government agency is called upon to administer it. Every requirement that the applicant must meet under the amnesty definition enacted will require her to present proof. Similarly, the government official adjudicating the claim will need to verify the bona fides of the individual claim. The more requirements for qualification, the greater the burden that will fall on the government officers called upon to review the documents. Likewise, the longer that a person has been in the country, the more potential points of inquiry the government has to pursue. Furthermore, as the amnesty definition is narrowed by more and more requirements, the burden on amnesty applicants will also grow.

One of the problems of the 1986 amnesty was its requirement that each applicant establish not just that she had been in the United States prior to the established cutoff date, but also that she had been here illegally and continu-

$174 \mathrm{Id}$.

$175 \mathrm{ld}$.

$176 \mathrm{Id}$.

${ }^{177}$ Security Through Regularized Immigration and a Vibrant Economy (STRIVE) Act of 2007, H.R. 1645, 110th Cong. $\$ 601$ (b) (2007). The statute would have created a "conditional nonimmigrant" classification allowing those granted this status to apply for status as lawful permanent residents. Id. $\$ 602$.

${ }^{178}$ Id. $\S 601(\mathrm{e})(1)(\mathrm{A})$.

${ }^{179}$ Id. $\$ 407$ (amending 8 U.S.C. $\$ 1255$ (2006 \& Supp. II 2008))

${ }^{180}$ S. 2611, 109th Cong. \& 613(a)(1)(A) (2006).

${ }^{181}$ H.R. $1645 \S 643(\mathrm{a})(1)$.

182 S. $2611 \S 613 ;$ H.R. $1645 \S 601$ (b).

${ }^{183}$ The estimates of the undocumented vary widely, but according to one well-known demographer, the number of undocumented in 2005 was nearly eleven million. JEFFREY S. Passel, Pew Hispanic Ctr., Estimates of the Size and Characteristics of the UndocuMENTED POPUlation 1 (2005), available at http://pewhispanic.org/files/reports/44.pdf. 
ously. ${ }^{184}$ The statute also required that the applicant be able to document that she had been physically present after the date of the amnesty's enactment. ${ }^{185}$ Applicants thus had to provide extensive documentation to establish unlawful status, residency, and physical presence. ${ }^{186}$ These requirements were burdensome on both the applicants and the agency. Consider the extensive documentation necessary to establish continuous residence or illegal status since December 31, 1981, and physical presence between the enactment and end of the amnesty application period. ${ }^{187}$ An applicant could demonstrate her illegal status through the difficult task of establishing an illegal entry or by remaining in the country after her authorization had expired. Proving residency and physical presence would also be a great challenge to an applicant who has been trying to remain invisible for the applicable amnesty period. Likewise, once an applicant demonstrated residency, disproving a person's claim of residence would be a great burden upon the agency, unless a person had been deported or had left through some other verifiable means.

One consequence of these seemingly simple requirements was that each applicant had to submit a voluminous set of documentation in order to satisfy the statute. In order to adjudicate claims, immigration officers reviewing the claim would have to interview the applicant and examine the documentation, which would constitute a time-consuming exercise. Amnesty applicants whose claims were denied might later be placed in removal proceedings where they could raise a host of defenses, which, depending on the facts, could include asylum, adjustment of status, or suspension of deportation, among others. ${ }^{188}$ These claims raised in the deportation hearing ${ }^{189}$ would then

${ }^{184}$ IRCA, Pub. L. No. 99-603, sec. 201, § 245A(a)(2)(A), 100 Stat. 3359, 3394 (codified as amended at 8 U.S.C. $\S 1255 \mathrm{a}(\mathrm{a})(2)(\mathrm{A})(2006)$ ); 8 C.F.R. $\$ 245 \mathrm{a} .1(\mathrm{c})(1)(\mathrm{i})(2008)$.

${ }^{185}$ IRCA $\$ 245 \mathrm{~A}(\mathrm{a})(3)(\mathrm{A}), 100$ Stat. at 3395 (codified as amended at 8 U.S.C. $\S 1255 \mathrm{a}(\mathrm{a})(3)(\mathrm{A})(2006))$. (2006))

${ }^{186}$ Id. $\$ 245 \mathrm{~A}(\mathrm{~g})(2)(\mathrm{D}), 100$ Stat. at 3401 (codified as amended at $\S 1255 \mathrm{a}(\mathrm{g})(2)(\mathrm{D})$

${ }^{187}$ The statute required a showing of illegal status before January 1, 1982. Id. $\S 245 \mathrm{~A}(\mathrm{a})(2)(\mathrm{A})$. Further, by regulations, absences that exceeded thirty days and were not preauthorized during the amnesty period were deemed to be sufficient to make the person ineligible. 8 C.F.R. $\$ 245 \mathrm{a} .1(\mathrm{~g})(2008)$. The agency, in error, assumed that any unauthorized absence during the amnesty period precluded eligibility, and it was only following a class action suit that these applicants were able to have their cases reconsidered. See Catholic Soc. Servs. v. Meese, 685 F. Supp. 1149 (E.D. Cal. 1988), aff'd sub nom. Catholic Soc. Servs. v. Thomburgh, 956 F.2d 914 (9th Cir. 1992), vacated sub. nom. Reno v. Catholic Soc. Servs., 509 U.S. 43 (1993), remanded to sub nom. Catholic Soc. Servs. v. INS, 232 F.3d 1139 (9th Cir. 2000) (en banc), remanded to sub nom. Catholic Soc. Servs., Inc. v. Ashcroft, 206 F.R.D. 654 (E.D. Cal. 2002).

${ }^{188}$ Under the 1986 amnesty, a person who had her application denied was not automatically placed in removal proceedings, as the statute assured applicants of confidentiality. See IRCA, secs. 201, 302, $\$ 245 A(c)(5), 210($ b)(6), 100 Stat. at 3397-98, 3419-20 (codified as amended at 8 U.S.C. $\$ \$ 1160($ b)(6), $1255 \mathrm{a}(\mathrm{c})(5)(2006))$. The purpose of the provision was to encourage as many applicants as possible to come forward without the risk of being deported. Indeed, Congress indicated that " $[t]$ he confidentiality of the records is meant to assure applicants that the legalization process is serious, and not a ruse to invite undocumented aliens to come forward only to be snared by the INS." H.R. REP. No. 99-682(I) (1986), as reprinted in 1986 U.S.C.C.A.N. 5649, 5677. 
be presented in an adversarial proceeding before an immigration judge, with further appeals to the Board of Immigration Appeals and the federal appellate courts. ${ }^{190}$ Up until the passage of legislation in 1996, if an applicant could establish that her deportation would cause "extreme hardship" either to the applicant or her spouse, parent, or child who was a U.S. citizen or permanent resident, she could seek suspension of deportation. ${ }^{191}$ Such claims might require extensive proof, and most applicants would not be able to qualify. These claims would, however, cause extended delays as a result of the time required to present the applications before immigration judges, the ensuing administrative appeals, and federal court review.

\section{A Proposal fOR Reform}

Similar to the rising concerns that gave way to the amnesty of 1986 , today's call for a new amnesty is an explicit recognition that the existing enforcement regime has not worked. Amnesty is a pragmatic solution, designed to relieve some of the pressures placed on the system. At the same time, it is an opportunity to retool the enforcement effort, and concentrate not on past, but on future violators, at least in those cases where the past violator does not present a threat to the safety and security of society at large.

While constructing the solution, it is important to remember that the overall objective of immigration laws of the United States is to keep the flow of people into the country to a manageable level, while preserving the interests of family unity and the need for labor. The laws establish a group of persons who may not enter the country or whom, if found within the borders, are to be ejected. These laws characteristically attempt to provide discretionary relief from deportation where certain hardships are established. Within this framework, when the immigration controls fail to be effective, a government has the choice either to engage in a serious crackdown or to create some sort of amnesty program by instituting a series of restrictive measures coupled with incentives. Many countries, particularly those that receive larger numbers of persons, either use registry or suspension of deportation to deal with the population of persons without legal status or create some form of amnesty. ${ }^{192}$

\footnotetext{
189 The term "deportation" is used here, for it was not until 1996 that Congress established the term "removal" for the proceeding to eject a person or prevent her admission. See AEDPA, Pub. L. No. 104-132, sec. 401, §§ 501-07, 110 Stat. 1214, 1258-68 (1996).

${ }^{190}$ See IRCA, sec. $201, \S 245 A(f)(4), 100$ Stat. at 3400 (codified as amended at 8 U.S.C. $\S 1255 \mathrm{a}(\mathrm{f})(4)(2006))$.

${ }^{191}$ See 8 U.S.C. $\$ 1254($ a)(1) (repealed 1996).

${ }^{192}$ For example, Spain, which had a population of over 40 million people in 2009 , enacted an amnesty in 2004 , which adjusted the status of nearly 600,000 people. See Real Decreto 2393/2004 de 30 de diciembre, por el que se aprueba el Reglamento de la Ley Orgánica 4/ 2000 , de 11 de enero, sobre derechos y libertades de los extranjeros en España y su integración social, B.O.E. 2005, 323 Nov. 3, 2005, available at http://noticias.juridicas.com/base_datos/
} 
One fact that should be clearer after this exploration of registry and suspension relief is that these means have long-standing historical precedent. Indeed, if Congress is poised to create an amnesty, it should amend the existing registry statute or borrow liberally from the language of registry and cancellation to craft a program that is simple, straightforward, and has few conditions. To meet the objectives previously identified, Congress should, much like the registry of 1929 , create a registry date that is within a period from five to seven years immediately preceding the enactment date of whatever statute is passed by Congress and signed into law by the President. While all of the objectives of an amnesty will not be met by the advancement of the registry date, many of the amnesty objectives can be met by a more generous registry date. The use of a five- to seven-year benchmark is admittedly an arbitrary one, but it comes from the realization that the further out the date, the fewer people who might qualify. Five to seven years is a period found in many provisions of the immigration laws where ties to the community and hardships are in question. ${ }^{193}$ If the legislature follows the existing standards for registry, under a new amnesty the applicant would still be required to establish good moral character at the time that the application is made and for some reasonable period of time prior to the application rather than throughout the period of residency. ${ }^{194}$ The person would have to

Admin/rd2393-2004.html\#au; CIA, The World Factbook-Spain, https:/www.cia.gov/library/ publications/the-world-factbook/geos/sp.html (last visited Oct. 27, 2009). This was not Spain's first attempt to enact an amnesty; it also created one in 1985, 1991, 1996, 2000, and 2001. See María Pabón López, Immigration Law Spanish-Style: A Study of Spain's Normalización of Undocumented Workers, 21 GEO. IMMIGR. L.J. 571, 575-77 (2007). According to population estimates available for Spain, as of June 30, 2009 it had 4.6 million persons with foreign registry certificates or valid residence cards. See Secretaria de Estado de Inmigracion y Emigracion, Estadisticas, http://extranjeros.mtin.es/es/InformacionEstadistica/ (last visited Oct. 27, 2009).

${ }^{193}$ For example, one part of the current cancellation of removal provision allows persons who have been permanent residents for five years and have lived in the United States for at least seven years to take advantage of the waiver. See 8 U.S.C. $\$ 1229$ b(a) (2006). Suspension of deportation was set at seven years and was later divided into two separate residency formulas, one that required seven years residency and the other ten years. See 8 U.S.C. $\S 1254(a)(1)(2)$ (repealed 1996). Similar standards apply to waivers of grounds of inadmissibility and deportability. See, e.g., 8 U.S.C. $\$ 1182(\mathrm{~h})(2006)$ (family ties with U.S. citizen or permanent resident and extreme hardship and rehabilitation); $\$ 1227(\mathrm{a})(1)(\mathrm{H})(2006)$ (family ties with U.S. citizen or lawful permanent residents and favorable discretionary factors). The Board of Immigration Appeals has adopted a flexible standard for the exercise of discretion in these cases that includes, among other things, family ties with U.S. citizens or permanent residents, hardship, circumstances surrounding the bad act, and evidence of good moral character. See In re Tijam, 22 I. \& N. Dec. 408, 412 (B.I.A. 1998).

${ }^{194}$ See In re Sanchez-Linn, 20 I. \& N. Dec. 362 (B.I.A. 1991). This conforms to the idea that a person who may have past transgressions should not be precluded if he is able to show that he has learned from his past. The notion that a person might be required to show rehabilitation following a criminal conviction has long been a part of the exercise of discretion in determining whether a waiver of inadmissibility and deportability might be granted to longterm residents facing possible removal. See, e.g., 8 U.S.C. $\$ 1182(\mathrm{~h})(1)(\mathrm{A})(\mathrm{iii})$ (relief under waiver of inadmissibility for past crimes); Matter of Marin, 16 I. \& N. Dec. 581, 587-88 (B.I.A. 1978) (rehabilitation as factor in relief under former 8 U.S.C. $\$ 1182(\mathrm{c})$ ); PalacioTorres v. INS, 995 F.2d 96, 99-100 (7th Cir. 1993). The immigration relief was commonly referred to as "212(c) relief." See Essentials of Immigration Law, supra note 14, at 75-76. 
establish that she is not deportable or inadmissible for national security reasons, such as being a terrorist or a Nazi. The only automatic or per se disqualifying criminal grounds for denying registration would be those involving serious crimes, particularly those involving violence or trafficking in drugs, or where the applicant is unable to show rehabilitation. However, a person should be able to establish rehabilitation if the fact finder is convinced that there is little likelihood that she will engage in criminal behavior. The fact finder would have to consider whether the person's later behavior shows that she has reformed or whether the reasons that caused the person to commit the crime in the first place no longer exist.

The amnesty should also not have too many complicating requirements, as each would reduce the possible persons who will qualify. In the 1929 registry, where the clear objective was to encourage as many as possible to apply, numerous immigrants were disqualified due to the difficulties of establishing continuous residency in the period following the cutoff date, while others were discouraged by the filing fee. ${ }^{195}$ This highlights the concern that each qualification creates its own evidentiary challenge and further burdens the adjudicatory process. The longer the qualifying period, the more documentation that will be required to establish a case, thereby further burdening the agency. Thus, advancing the registry date even closer in time to the statute's enactment would be prudent and advisable, in order to avoid leaving a large portion of the undocumented population outside of the amnesty program's reach.

As previously discussed, to be effective, any amnesty should have the goal of encouraging as many qualified applicants as possible to apply. However, merely encouraging applicants to apply is not enough to deliver a successful amnesty. In the end, the agency charged with administering the program and managing the newly tooled immigration system must be able to handle an amnesty program designed around this objective. This means that great care should be taken not to overburden the amnesty program with administrative hurdles and to assure that those responsible for adjudicating the claims can do so efficiently. If the agency is unable to handle a significantly increased workload, these problems would likely spill over into increased pressures on the enforcement side. Therefore, the simpler and more streamlined the amnesty program, the lesser the burden that will be placed on the overall immigration system.

One critique of this proposal might be that the registry of 1929 did not encompass as large of a population of eligible immigrants as exists at the

In 1996, the relief was incorporated and modified into cancellation of removal-one for longterm permanent residents and the other for non-permanent residents. Id. at 75 .

${ }_{195}$ Information regarding the program is rather scant, but according to the Commissioner General's report of 1932, in that year the agency issued 14,144 certificates and denied six percent based on the inability to satisfy the requirements. 1932 IMMIGRATION REPORT, supra note 48 , at 36. 
present time, and, therefore, it is not an appropriate model. ${ }^{196}$ While it is true that the registry enacted in 1929 did not provide legal status to as large of a group as could qualify here, the reason for using registry is that its use has strong historical roots in our immigration tradition and is far less cumbersome than an amnesty. Furthermore, one of the political arguments used against the 1986 amnesty that clouds the present debate is that amnesty creates a bad historical precedent and encourages illegal immigration. ${ }^{197}$ Yet, registry, suspension, and cancellation are all ameliorative tools designed to relieve a burdened immigration system and effectively deal with a large undocumented population. The core of this debate is whether amnesty is the cause of illegal migration or one of a number of tools for dealing with the problem.

For the most part, this Article's proposal and its justification present a pragmatic argument and deliberately avoid the debate about the merits of comprehensive immigration reform. The contours of whatever amnesty is finally enacted will determine the success or failure of legal immigration reform. If the amnesty program fails to meet the objective of bringing the large undocumented population out from the shadows, enforcement efforts will overwhelm the immigration system, and comprehensive reform will fail.

\section{Conclusion}

As presently written into the immigration statute, neither registry, suspension of deportation, nor cancellation relief is a true amnesty, for an amnesty contemplates the wholesale regularization of a large population. When enacted, these immigration benefits had the potential to be used as a way of dealing with compelling humanitarian immigration cases. However, the many changes that Congress has made to these remedies have limited their availability to only a small portion of the undocumented population. While generous, the measures of the past were complicated remedies that left large numbers of undocumented persons outside of their coverage. These immigration remedies were seen as ameliorative devices to deal with the hard-

196 The types of immigration restrictions that created the large undocumented population that we have today had only just been put into effect twelve years before the first registry was enacted. See Registry Act of 1929, ch. 536, \& I(a)(1), 45 Stat. 1512, 1513; Immigration Act of 1917, ch. 29, 39 Stat. 874 (repealed 1952).

197 Throughout the debate on comprehensive immigration reform opponents argued that amnesty would reward illegal behavior and act as a magnet for further illegal immigration. Indeed, President George W. Bush, careful to avoid being seen as supporting an amnesty stated:

Now, this isn't an amnesty program. Let me be clear about this. This is a temporaryworker program to be registered and above-board. I oppose amnesty because amnesty-amnesty would encourage further illegal immigration. And I oppose amnesty because amnesty would reward those who have broken the laws of the United States.

President's Remarks to the United States Conference of Mayors, 40 WEeKLy CoMP. Pres. Doc. 123 (Jan. 26, 2004). 
ships that would be inflicted on citizens and residents who formed part of the communities and families of the person who was without status or otherwise deportable. Granting these benefits was not a pure act of charity, for these remedies allowed the immigration authorities to focus their limited enforcement resources on those who truly deserved the amnesty. Therefore, a less complicated and broader immigration benefit would be to use registry and cancellation as originally envisioned when first enacted. Using a remedy grounded in the existing immigration statute provides the added benefit of familiarity for the agency responsible for its implementation. In the end, the success of the amnesty program will depend on the meritorious cases of hardship that it resolves. If its coverage is too narrow, renewed calls for reform will soon arise.

In 1975, the late Charles Gordon, the immigration scholar and former general counsel to the Immigration and Naturalization Service, argued for far-reaching changes to the immigration laws. ${ }^{198}$ Gordon noted that the removal of discretion to ameliorate the terrible hardships that resulted from deportation-the wrenching and tearing apart of families was one of the most serious problems that existed in immigration laws. The moral critique leveled by Gordon carries more force today, for the problems faced by policy makers in 1975 pale in comparison to what we are witnessing today. ${ }^{199}$ In an era when border and national security loom large as issues requiring attention, the need to bring the undocumented population from out of the shadows requires serious attention from our political leaders. This Article tackles a small but significant part of the reform puzzle.

${ }^{198}$ Charles Gordon, The Need to Modernize our Immigration Laws, 13 SAN DIEGo L. REV. 1 (1975). Among other things, Gordon argued for the advancement of the registry date. Id. at 25.

199 While getting a clear picture of the number of undocumented persons in the United States may be an elusive task, we may still be able to draw comparisons between the numbers of 1986 and the present. The estimates of numbers of undocumented in the period preceding the 1986 program ranged from 2 to 4 million persons. See NAT'L ACAD. OF SCI., IMmigration STATISTICS: A STORY OF NEGLECT 87-88 (1985). Estimates of the number in the current period range widely. In 2003, the number was 5 to 5.8 million. Press Release, Immigration \& Nationalization Serv., INS Releases Updated Estimates of U.S. Undocumented Resident Population (Jan. 31, 2003). In 2008, the number was said to be 11.6 million. MichaEL HoEfer ET Al., Office of Immigration Statistics, Dep't of Homeland Sec., Estimates of the Unauthorized Immigrant Population Residing in the United States: January 2008 (2009). 